$12-2021$

\title{
Securities Law: Overview and Contemporary Issues
}

Neal Newman

Texas A\&M University School of Law, nnewman@law.tamu.edu

Lawrence J. Trautman

Prairie View A\&M University, lawrence.j.trautman@gmail.com

Follow this and additional works at: https://scholarship.law.tamu.edu/facscholar

Part of the Internet Law Commons, Law and Society Commons, and the Securities Law Commons

\section{Recommended Citation}

Neal Newman \& Lawrence J. Trautman, Securities Law: Overview and Contemporary Issues, 16 Ohio St. Bus. L.J. 149 (2021).

Available at: https://scholarship.law.tamu.edu/facscholar/1528

This Article is brought to you for free and open access by Texas A\&M Law Scholarship. It has been accepted for inclusion in Faculty Scholarship by an authorized administrator of Texas A\&M Law Scholarship. For more information, please contact aretteen@law.tamu.edu. 


\title{
SECURITIES LAW: OVERVIEW AND
}

\section{CONTEMPORARY ISSUES}

\author{
Neal F. Newman* \& Lawrence J. Trautman**
}

\begin{abstract}
This is not your grandfather's SEC anymore. Rapid technological change has resulted in novel regulatory issues and challenges, as law and policy struggles to keep pace. The U.S. Securities and Exchange Commission (SEC) reports that "the U.S. capital markets are the deepest, most dynamic, and most liquid in the world. They also have evolved to become increasingly fast and extraordinarily complex. It is our job to be responsive and innovative in the face of significant market developments and trends." With global markets increasingly interdependent and interconnected and, "as technological advancements and commercial developments have changed how our securities markets operate, our ability to remain an effective regulator requires us to continuously monitor the market environment and, as appropriate, adjust and modernize our expertise, rules, regulations, and oversight tools and activities." The success or failure of our society, jobs of a global workplace, and the ability of families everywhere to feed, clothe, and house themselves depends on the success of the SEC in providing fair and open access to capital through efficient markets.

Our paper proceeds in eight parts. First, we explain the genesis and role of the Securities and Exchange Commission (SEC). Second, the definition of and what exactly constitutes a "security" is provided. Third, the securities issuance process is discussed. Fourth, we focus our discussion on The Division of Enforcement. Fifth, we discuss corporate governance and the SEC. Sixth, we explore the difficult task of governing during times of rapid technological change. Seventh, we examine contemporary issues that face the Commission. And last, we conclude.
\end{abstract}

Keywords: blockchain, board of directors, corporate governance, corporation finance, cybersecurity, D\&O insurance, economic and risk analysis, enforcement, environmental, social, and governance (ESG), examinations, financial markets, FCPA, GameStop, Howey, innovation, investment management, Koskot, registration, regulation, Robinhood, trading and markets, United Housing, virtual currencies.

\section{CONTENTS}




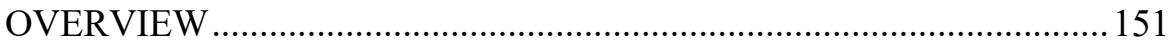

I. THE SECURITIES AND EXCHANGE COMMISSION ............151

History and Role................................................................... 152

Protecting America's Securities Markets .................................... 152

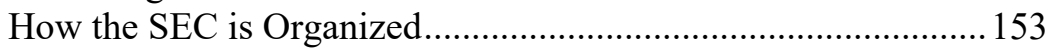

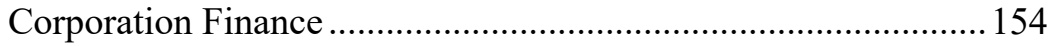

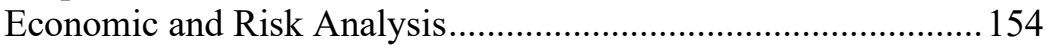

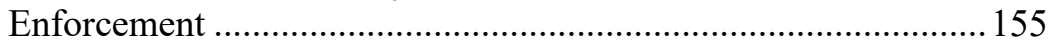

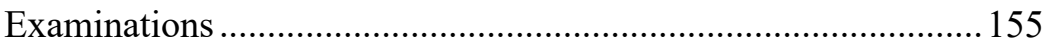

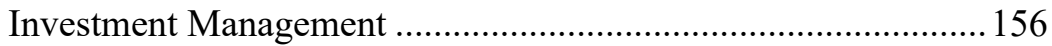

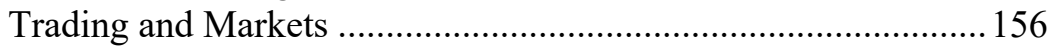

Organization By Office \& Regional Branches............................. 156

SEC As Information Source ........................................................ 157

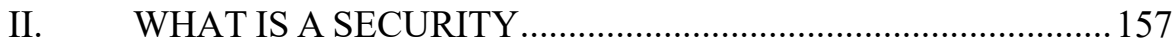

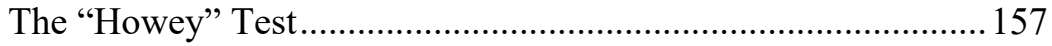

United Housing - When "Stock" is Not a Security - Focus on

Economic Substance.................................................................... 161

Koskot - Ponzi Schemes - the "Common Enterprise" and Efforts of

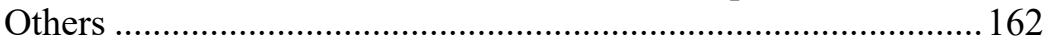

III. THE SECURITIES ISSUANCE PROCESS ................................165

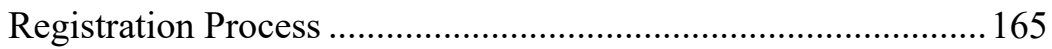

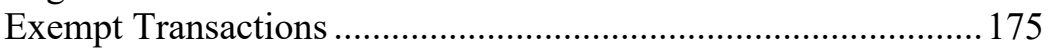

The Common Private Offering Exemptions................................. 176

IV. DIVISION OF ENFORCEMENT ........................................... 182

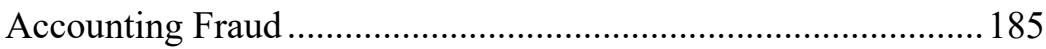

Covid-19 Pandemic ................................................................ 187

Misconduct By Issuers and Registrants..................................... 190

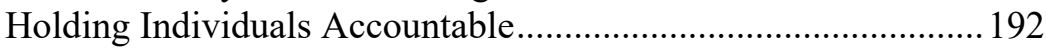

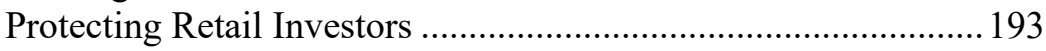

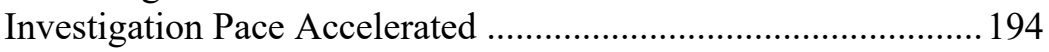

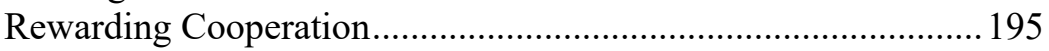

Foreign Corrupt Practice Act (FCPA)....................................... 197

V. CORPORATE GOVERNANCE AND THE SEC .........................204

The Duties and Responsibilities of Corporate Directors..............205

How Boards Organize Their Work ............................................206

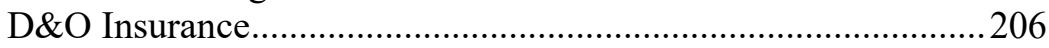

VI. GOVERNING TECHNOLOGY CHALLENGES ......................207

Challenge of Technology .......................................................208

Cybersecurity and Financial Markets .........................................210

Innovation and Financial Technology ......................................210

Virtual Currencies, Tokens, and the ICO Regulation Challenge .211

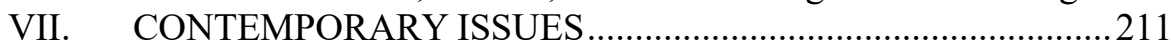

The Robinhood-GameStop Drama .............................................211

Environmental, Social, and Governance (ESG) Issues ................216

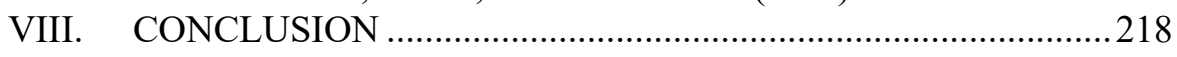




\section{OVERVIEW}

The U.S. Securities and Exchange Commission (SEC) reports that the "U.S. capital markets are the deepest, most dynamic, and most liquid in the world. They also have evolved to become increasingly fast and extraordinarily complex. It is our job to be responsive and innovative in the face of significant market developments and trends." With global markets becoming increasingly interdependent and interconnected and, "as technological advancements and commercial developments have changed how our securities markets operate, our ability to remain an effective regulator requires us to continuously monitor the market environment and, as appropriate, adjust and modernize our expertise, rules, regulations, and oversight tools and activities." "The success or failure of our society, jobs of a global workplace, and the ability of families everywhere to feed, clothe, and house themselves depends on the success of the SEC in providing fair and open access to capital through efficient markets.

Our paper proceeds in eight parts. First, we explain the genesis and role of the Securities and Exchange Commission (SEC). Second, the definition of, and what exactly constitutes, a "security" is provided. Third, the securities issuance process is discussed. Fourth, we focus our discussion on The Division of Enforcement. Fifth, we discuss corporate governance and the SEC. Sixth, we explore the difficult task of governing during times of rapid technological change. Seventh, we examine contemporary issues that face the Commission. And last, we conclude.

\section{I.THE SECURITIES AND EXCHANGE COMMISSION}

In the autumn of 1929 the mightiest of Americans were, for a brief time, revealed as human beings. Like most humans, most of the time, they did some very foolish things... Things that in other times were concealed by a heavy façade of dignity now stood exposed, for the panic suddenly,

* BBA (Accounting) University of Michigan; J.D. (Banking, Corporate Finance, and Securities Law) Howard University School of Law. Mr. Newman is Professor of Law at Texas A\&M University School of Law. He may be contacted at nnewman@1aw.tamu.edu.

** BA, The American University; MBA, The George Washington University; J.D., Oklahoma City University School of Law. Mr. Trautman is Associate Professor of Business Law and Ethics at Prairie View A\&M University, and past-president of the New York and

Washington/Baltimore chapters of the National Association of Corporate Directors (NACD). He may be contacted at Lawrence.J.Trautman@gmail.com.

${ }^{1}$ What We Do, SEC, https://www.sec.gov/about/what-we-do [https://perma.cc/5MQC-8LVR] (last modified Dec. 18, 2020).

${ }^{2} I d$. 
almost obscenely, snatched this façade away...

Since 1929 we have enacted numerous laws designed to make securities speculation more honest and, it is hoped, more readily restrained. None of these is a perfect safeguard. The signal feature of the mass escape from reality that occurred in 1929 and before- and which has characterized every previous speculative outburst from the South Sea Bubble to the Florida land boom- was that it carried authority with it...

The wonder, indeed, is that since 1929 we have been spared so long. One reason, without doubt, is that the experience of 1929 burned itself so deeply into the national consciousness. It is worth hoping that a history such as this will keep bright that immunizing memory for a little longer.

John Kenneth Galbraith

Paul M. Warburg

Harvard University ${ }^{3}$

\section{History and Role}

It was The Great Crash of 1929, failure of securities markets, and subsequent economic demise of the early 1930s that led to the need for a Securities and Exchange Commission. Professor Galbraith writes, "Wall Street...is of considerable importance in the American economy. The stock market crash and the speculation which made it inevitable had an important effect on the performance, or rather the malperformance, of the economy in the ensuing months and years." 4 Job lost resulted, food lines and human suffering abounded, bank failures were widespread, all hampered by the "poor state of economic intelligence." 5

\section{Protecting America's Securities Markets}

In the SEC's 2020 annual report for the Division of Enforcement, despite operating during a global pandemic, "the Commission brought 715 enforcement actions -405 of which were 'standalone' actions. Seventy-two percent of these stand-alone actions included charges against one or more individuals. The Commission also obtained more than 476 bars or

\footnotetext{
3 John Kenneth Galbraith, The Great Crash: 19293 (Houghton Mifflin, 1961).

${ }^{4}$ Id. at 2 .

${ }^{5} \mathrm{Id}$. at 187 .
} 
suspensions against market participants and suspended trading in the securities of 196 issuers." "To better understand the Commission's role in Capital markets, we learn that during FY2020, the Division of

Enforcement, "triaged approximately 23,650 tips, complaints, and referrals and opened close to 1,200 new inquiries and investigations. Finally, the Commission obtained judgments and orders totaling approximately $\$ 4.68$ billion in disgorgement and penalties-the highest amount on record." " We will now explain how the SEC is organized and comment briefly on the operations of its various divisions.

\section{How the SEC is Organized}

The SEC is organized by functional area into the divisions of: Corporation Finance; Economic and Risk Analysis; Enforcement; Examinations; Investment Management; and Trading and Markets. An organization chart is presented as Exhibit 1. A brief introduction to the role of each division is now provided.

Exhibit 1

SECURITIES AND EXCHANGE COMMISSION

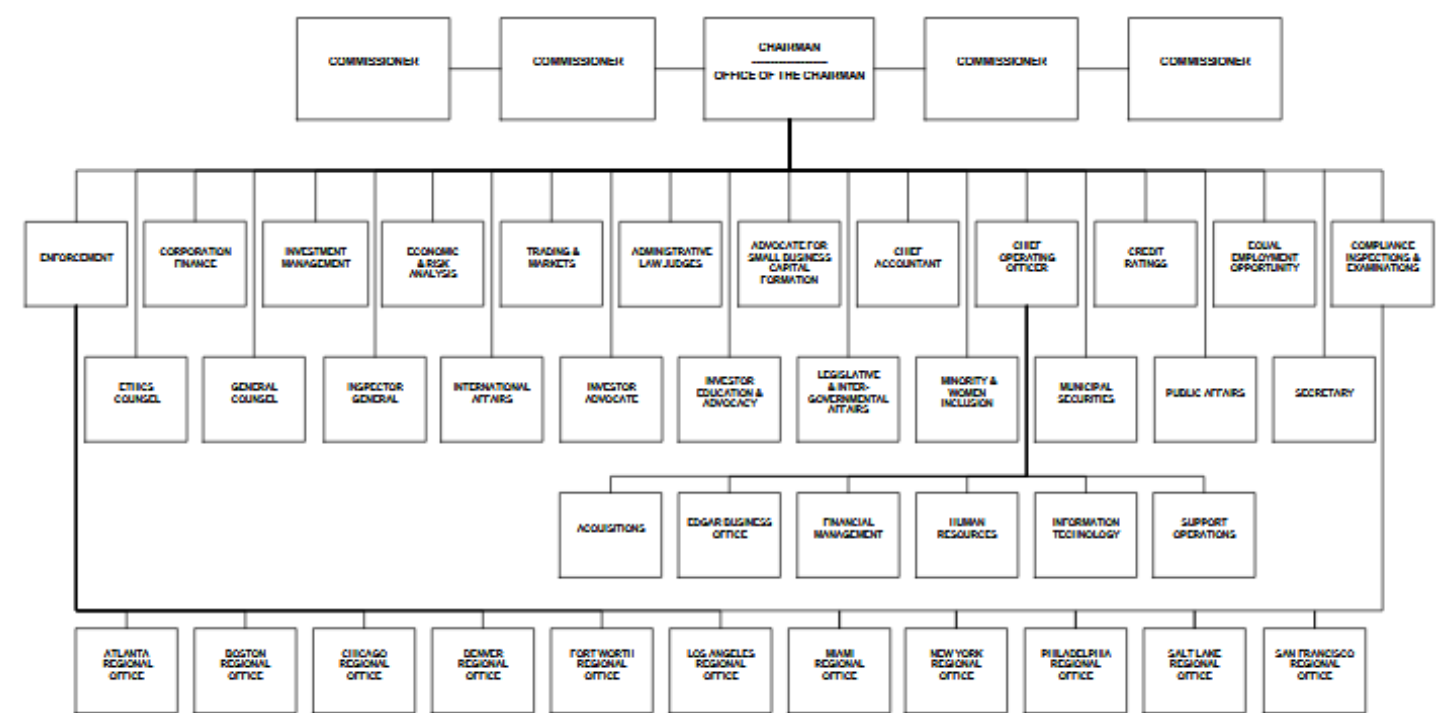

${ }^{6}$ U.S. SEC. \& EXCh. COMM'N, 2020 ANNUAL REPORT Division OF ENFORCEMENT, 7 (Nov. 2, 2020), https://sec.gov/enforce/reports-andpublications/annual-reports/enforcement-2020-annual-report [https://perma.cc/E8TJ-M4EK] (last viewed Feb. 26, 2021) [hereinafter SEC 2020 ANNUAL REPORT].

${ }^{7}$ Id.; see also MARC I. STEINBERG, THE FEDERALIZATION OF CORPORATE GovernanCE (Oxford Univ. Press, 2018). 
Source: $\mathrm{SEC}^{8}$

\section{Corporation Finance}

The Division of Corporation Finance provides a valuable role toward supporting "the Commission's mission to protect investors, maintain fair, orderly, and efficient markets, and facilitate capital formation." Accordingly, "the Division... seeks to ensure that investors are provided with material information in order to make informed investment decisions, both when a company initially offers its securities to the public and on an ongoing basis as it continues to give information to the marketplace." 10 Interpretative guidance is also provided by the Division "to companies with respect to SEC rules and forms and [the Division] makes recommendations to the Commission regarding new rules and revisions to existing rules." 11 For example, the Division of Corporation Finance provides staff guidance and interpretations about: "Accounting and Financial Reporting Guidance; [Corporate Finance] Disclosure Guidance Topics; Compliance and Disclosure Interpretations; Dear CFO Letters and Other Disclosure Guidance; Division Policy Statements; EDGAR Filer Guidance; Filing Review Process; Financial Reporting Manual; No-Action, Interpretative and Exemptive Letters; Staff Accounting Bulletins; and Staff Legal Bulletins."12

\section{Economic and Risk Analysis}

Elsewhere, professor Trautman discusses the appointment of Professor Henry T.C. Hu, who served as the SEC's inaugural Director of the Division of Risk, Strategy, and Financial Innovation (2009-2011), following the 2007-08 mortgage market meltdown and financial crisis. This crisis brought attention to the Commission that they needed someone to focus on the systematic risk associated with capital markets. Professor $\mathrm{Hu}$ observes that:

Modern financial innovation has resulted in objective realities that are far more complex than in the past, often beyond the capacity of the English language, accounting terminology, visual display, risk measurement, and other tools on which all depictions must primarily rely." These same characteristics of highly sophisticated data encryption

\footnotetext{
${ }^{8}$ SEC Employee Guide Org. Chart, SEC, https://www.sec.gov/about/secorg.pdf [https://perma.cc/B3NM-82SM] (last modified Nov. 22, 2016).

${ }^{9}$ Division of Corporation Finance, SEC, https://www.sec.gov/page/corpfin-section-landing [https://perma.cc/UPL7-74DQ] (last modified Jan. 31, 2017).

${ }^{10} \mathrm{Id}$.

${ }^{11} I d$.

${ }^{12} I d$.
} 
and transmission systems apply communications systems as well. Professor $\mathrm{Hu}$ further

observes that "such characteristics can be so complex that even 'objective reality' is subject to multiple meanings. ${ }^{13}$

The SEC explains, "The Division of Economic and Risk Analysis (DERA) was created in September 2009 to integrate financial economics and rigorous data analytics into the core mission of the SEC. The Division is involved across the entire range of SEC activities, including policymaking, rule-making, enforcement, and examination."14

\section{Enforcement}

The Division of Enforcement according to the Commission, "was created in August 1972 to consolidate enforcement activities that previously had been handled by the various operating divisions at the Commission's headquarters in Washington... enforcement staff conducts investigations into possible violations of the federal securities laws, and prosecutes... civil suits in the federal counts [and brings] administrative proceedings." 15 Because of the Enforcement Division's disproportionate importance, we provide extensive coverage of its various activities later. ${ }^{16}$

\section{Examinations}

It is The Division of Examinations that "conducts the SEC's National Exam Program"17 with a stated "mission... to protect investors, ensure market integrity and support responsible capital formation through risk-focused strategies that: (1) improve compliance; (2) prevent fraud; (3) monitor risk; and (4) inform policy." 18 The Division's work product, "[the] results of... examinations are used by the SEC to inform rule-making initiatives, identify and monitor risks, improve industry practices and pursue misconduct." 19

\footnotetext{
${ }^{13}$ Lawrence J. Trautman, Cybersecurity: What About U.S. Policy?, 2015 U. ILL. J. L. TECH. \& POL'Y 341, 349 (2015) (citing Henry T.C. Hu, Too Complex to Depict? Innovation, "Pure Information," and the SEC Disclosure Paradigm, 90 Tex. L. REv. 1601, 1602, (2012) (describing the environment of risk inherent in complex financial instruments associated with and subsequent to the 2008-2009 global financial crisis)).

${ }^{14}$ Economic and Risk Analysis, SEC, https://www.sec.gov/dera [https://perma.cc/NSK3-PXJ5] (last modified Jan. 17, 2020).

${ }^{15}$ Division of Enforcement, SEC, https://www.sec.gov/page/enforcementsection-landing [https://perma.cc/KZ9U-EXRR] (last modified Apr. 14, 2015).

${ }^{16}$ See infra § IV.

${ }^{17}$ Division of Examinations, SEC, https://www.sec.gov/exams [https://perma.cc/7TYB-UBWB] (last modified Apr. 16, 2020).

${ }^{18} I d$.

${ }^{19} I d$.
} 


\section{Investment Management}

According to the Commission, "The Division of Investment Management, "supports the Commission in its mission to protect investors, maintain fair, orderly and efficient markets, and facilitate capital formation. ${ }^{" 20}$ It is the primary responsibility of The Division to "administ[er] the Investment Company Act of 1940 and Investment Advisors Act of 1940, which includes developing regulatory policy for investment companies (e.g., mutual funds, including money market funds, closed-end funds, business development companies, unit investment trusts, variable insurance products, and exchange-traded funds) and for investment advisers." 21

\section{Trading and Markets}

In brief, The Division of Trading and Markets at the SEC, "establishes and maintains standards for fair, orderly, and efficient markets. The Division regulates the major securities market participants, including broker-dealers, self-regulatory organizations (such as stock exchanges, FINRA, and clearing agencies), and transfer agents." ${ }^{, 2}$

\section{Organization By Office \& Regional Branches}

For purposes of efficiency, much of the specialized work of the $\mathrm{SEC}$ is conducted within its various Offices and regional branches. The Regional Offices are located in: Atlanta; Boston; Chicago; Denver; Fort Worth; Los Angeles; Miami; New York; Philadelphia; Salt Lake City; and San Francisco. ${ }^{23}$ These specialized SEC "offices" include:

the EDGAR business Office; Office of Acquisitions; Office of Administrative Law Judges; Office of the Advocate for Small Business Capital Formation; Office of the Chief Accountant; Office of the Chief Operating Officer; Office of the Chief Risk Officer; Office of Credit Ratings; Office of Equal Employment Opportunity; Office of Ethics Counsel; Office of Financial Management; Office of the General Counsel; Office of Human Resources; Office of Information Technology; Office of Inspector General; Office of International Affairs; Office of the Investor Advocate; Office of the Investor Education and Advocacy; Office of Legislative and Intergovernmental Affairs; Office of Minority and Women Inclusion; Office of Municipal

${ }^{20}$ Division of Investment Management, SEC, https://www.sec.gov/investment-management [https://perma.cc/J4EPXYLJ] (last visited Jan. 22, 2021).

${ }^{21} I d$.

${ }^{22}$ Trading and Markets, SEC, https://www.sec.gov/divisions/tradingmarkets [https://perma.cc/8G36-Q5BP] (last modified Oct. 1, 2020).

${ }^{23}$ SEC Regional Offices, SEC, https://www.sec.gov/page/sec-regionaloffices [https://perma.cc/V9BW-MRWP] (last modified Aug. 11, 2016). 
Securities; Office of Public Affairs; Office of the Secretary; and Office of Support Operations... ${ }^{24}$

\section{SEC As Information Source}

The SEC website, www.sec.gov, provides a robust source of information for: investors; accounting and legal practitioners; those seeking business, industry and competitive intelligence; and the general public. For example, a recent highly controversial issue, as reflected by Congressional hearings, is the privacy issue of user's personal information held by widely used technology giants such as Facebook or Google.

\section{II.WHAT IS A SECURITY}

When addressing the question, "What is a Security?" - A corollary question is, "Why should we care?" - The threshold question of whether or not a transaction is a security is important because the implications are far reaching. Crossing the securities definitional trip wire has a rippling effect. Once the determination is made that the transaction in question is in fact a security, then the transaction now comes under the purview of all applicable federal and state securities laws; a mine field of compliance obligations and culpable activity for the unenlightened or the unaware.

Once the parties find themselves in the securities law space they must now be mindful that they are, at all times, remaining compliant with all applicable federal and state securities laws. These requirements include issues such as when and how to disclose pertinent financial and business information regarding the issuer, when the securities must be registered, and a host of other compliance issues. Thus, the threshold question is an important one. If it turns out that the transaction in question is not a security, then the parties don't have to worry about securities law compliance, although other rules may apply.

\section{The "Howey" Test}

The volume of rules, regulations, acts, and statutes that comprise the securities law's regulatory regime are voluminous. Practitioners and scholars alike will digest a fraction of what is out there even after decades of practice. As in most areas of the law, the key to resolving any securities related issue is knowing where to look given the issue at hand. Determining whether or not a certain transaction is a security is no exception.

\section{The Starting Point}

The Securities Act of 1933 ("'33 Act") is the starting point; born primarily due to the Great Depression of 1929, although there have been

${ }^{24}$ SEC Divisions Homepages, SEC, https://www.sec.gov/divisions.shtml [https://perma.cc/25FP-S358] (last visited Dec. 17, 2020). 
some amendments since that time. ${ }^{25}$ The ' 33 Act remains close to the original version that was penned back in 1933. The ' 33 Act, is the first reference point when dealing with transactional matters such as issuing securities either publicly or privately. The ' $33 \mathrm{Act}$ is also the reference point when grappling with the question "What is a Security?"

The '33 Act's Section 2. a.1

The '33 Act's Section 2 - (Definitions; Promotions of Efficiency, Competition, and Capital Formation) is the section that houses a number of '33 Act definitions. ${ }^{26} \mathrm{Up}$ front and the very first item identified - thus signifying its importance-is the definition of a security. Section 2.a.1. reads as follows:

(a) DEFinitions - When used in this subchapter, unless the context otherwise requires-

(1) The term "security" means any note, stock, treasury stock, security future, security-based swap, bond, debenture, evidence of indebtedness, certificate of interest or participation in any profit-sharing agreement, collateraltrust certificate, preorganization certificate or subscription, transferable share, investment contract, votingtrust certificate, certificate of deposit for a security, fractional undivided interest in oil, gas, or other mineral rights, any put, call, straddle, option, or privilege on any security, certificate of deposit, or group or index of securities (including any interest therein or based on the value thereof), or any put, call, straddle, option, or privilege entered into on a national securities exchange relating to foreign currency, or, in general, any interest or instrument commonly known as a "security", or any certificate of interest or participation in, temporary or interim certificate

${ }^{25}$ The 1933 Securities Act was the first major federal securities law passed following the stock market crash of 1929. The law is also referred to as the Truth in Securities Act, the Federal Securities Act, or the 1933 Act. It was enacted on May 27, 1933 during the Great Depression. (President Roosevelt stated that the law was aimed at correcting some of the wrongdoings that led to the exploitation of the public). The wrongdoings included insider trading, the sale of fraudulent securities, secretive and manipulative trading to drive up share prices, and other acts that some financial institutions and professional stock traders engaged in, to the disadvantage of ordinary individual investors. See The 1933

Securities Act- "The Truth in Securities Act", CORPORATEFINANCEINSTITUTE.COM (2021), https://corporatefinanceinstitute.com/resources/knowledge/tradinginvesting/1933-securities-act-truth-securities/ [https://perma.cc/NSA5$5 \mathrm{M} 7 \mathrm{~L}]$.

${ }^{26}$ See Securities Act of $1933 \S 2(a)(1)-(19), 15$ U.S.C. $\S 77 b$ (2021). 
for, receipt for, guarantee of, or warrant or right to subscribe to or purchase, any of the foregoing. ${ }^{27}$

True to form and endemic throughout the ' 33 Act's language, the Act tends to define things broadly and leaves ultimate interpretation to rule making provisions promulgated through the Securities and Exchange Commission as well as through case law. Turning back to the question of "what is a Security?" and appreciating how the above definition fits into that analysis - as the definition portends, there are a number of "instruments" that may fall under the definition of a security. As a practical matter and in practice, the courts have narrowed the approach down to some finite analytical tools to answer the question as to whether or not any particular transaction constitutes a securities transaction.

\section{The "Howey" Test -}

When addressing whether or not a certain transaction constitutes a stock transaction, the analytical approach distills as follows. For conventional stock shares, no test is required. Ownership shares in companies such as Wal-Mart or Home Depot are your "Garden Variety" stock transactions that require no further analytical assessing to determine their nature or character. ${ }^{28}$ But transactions off the beaten path are the ones that prompted the analytical approach first penned in a United States Supreme Court case decided in 1946 and is still in effect today. ${ }^{29}$

The Investment Contract

Typically, those stock transactions that fall outside the conventional Walmart or Home Depot shares alluded to earlier are analyzed under the '33 Act's Section 2(a)(1) as an Investment Contract. ${ }^{30}$ As is the case with many matters found in the ' 33 Act, an Investment Contract is not specifically defined. SEC vs. W.J. Howey Co. is the case where the court marked the definitional contours of an Investment Contract and therefore a securities transaction. ${ }^{31}$

The Howey case involved a citrus grove company called the W.J. Howey Company. ${ }^{32}$ The W.J. Howey Company sold units of citrus groves

${ }^{27}$ Securities Act of 1933 § 2(a)(1), 15 U.S.C. § 77b (2021).

${ }^{28}$ See Walmart, Inc., Annual Report (Form 10-K), p. 56 (Mar. 19, 2021), https://www.sec.gov/ix?doc=/Archives/edgar/data/0000104169/00001041 $6921000033 / \mathrm{wmt}-$

20210131.htm\#iaaf0cabf1f7048c9b7e317b3e9c1cfc5 115 [https://perma.cc/F94Z-96BP]; see also The Home Depot Inc., Annual Report (10-K), p.39 (Mar. 24, 2021), https://www.sec.gov/ix?doc=/Archives/edgar/data/0000354950/00003549 5021000089/hd-20210131.htm\#i767754147c274b8fbbfeb5ffedb7558f_43 [https://perma.cc/7M7S-XGHM].

${ }^{29}$ See SEC v. W.J. Howey Co., 328 U.S. 293 (1946).

${ }^{30}$ Securities Act, supra note 26.

${ }^{31}$ See W.J. Howey Co., 328 U.S. at 298-99.

${ }^{32} I d$. at 294. 
to anyone wishing to and having an interest to buy into the endeavor. ${ }^{33}$ The investor had the option of hiring a management company to cultivate the groves and make them ready for sale. ${ }^{34}$ Alternatively, and what was typically the case, the W.J. Howey Company also had a management company available, the Howey in the Hills Company who would, for an additional fee, cultivate the purchase of orange groves and make the groves ready for sale. ${ }^{35}$ Though it was not clear from the case how the dispute arose, the key question that the case addressed was whether the nature of the transactions in question constituted securities transactions. ${ }^{36}$ The Court's answer to that question was ultimately "yes."

\section{The "Howey" Test Applied}

The Court in Howey analyzed the nature of these transactions, focusing on their economic substance. ${ }^{38}$ The Court looked at the relationship between those that were purchasing tracts of citrus groves and the company from whom such purchases were being made. It was the asymmetrical nature of the relationship between the W.J. Howey Company and the investors that factored significantly in the Court's decision. ${ }^{39}$ In its opinion, the Court recognized that the transactions in question were 1) investments of money; 2) in a common enterprise; 3 ) with investors expecting or being led to expect profits; 4 ) whose profits would be derived solely from the efforts of others -(versus the investor's efforts themselves).$^{40}$ In the Court's assessment, when all four of these elements are present, then the transaction in question will meet the legal definition of an Investment Contract and therefore meet the legal definition of a security. ${ }^{41}$ These four elements comprise what are referred to, to this day, as the Howey test.

The Focus on Economic Substance

As alluded to earlier, key in understanding the Howey test's underpinnings is the test's focus on a transaction's economic substance. ${ }^{42}$ The transactions as described in Howey were ones where you had one group, the "investors", entrusting their money to another, the company, and relying on that company's efforts to take the investor's money and use that

${ }^{33}$ See id. at 295.

${ }^{34} \mathrm{Id}$. at 296.

${ }^{35} \mathrm{Id}$. at 295.

${ }^{36}$ See id. at 294.

${ }^{37}$ Id. at 300.

${ }^{38}$ See id. at 298.

${ }^{39}$ See id. at 299-300 (the Court noting that the Howey Company offered this opportunity to persons who reside "in distant localities and who lack the equipment and experience requisite to the cultivation, harvesting, and marketing of the citrus products. Such persons have no desire to occupy the land or to develop it themselves; they are attracted solely by the prospects of a return on their investment").

${ }^{40}$ See id. at 298-99.

${ }^{41}$ Id.

${ }^{42}$ See id. at 298. 
money for what the investor hopes is a profitable endeavor that will generate a return on that money. ${ }^{43}$ Therefore, in substance, these transactions are similar to owning shares in a Home Depot. For example, as a Home Depot shareholder, one's expectation for buying Home Depot shares is that the company will work to be profitable and the share's value will appreciate. The investor is not expected nor required to go work at a Home Depot to help Home Depot become more profitable - perhaps directing patrons to the plumbing or lumber sections. Any appreciation in Home Depot's share value is derived solely from Home Depot's efforts exclusively. The investor can shop at Lowe's - (though that would be against the investor's financial interest) and never step foot inside a Home Depot store but nonetheless will realize an increase on his investment if the value of Home Depot's shares increase.

Thus, when analyzing any transaction using the Howey test, it is important to keep the test's focus on economic substance in mind. The "economic substance" is that situation where one party entrusts their money to another, and the latter takes and uses that money to grow the venture.

Appreciating the nature of this asymmetric relationship helps in guiding the analysis and determining whether a particular transaction would be considered a security.

\section{United Housing - When "Stock" is Not a Security - Focus on Economic Substance}

Illustrating the principle that courts will focus on the economic substance of transactions versus merely acquiescing to a transaction's labels is the case of United Housing Foundation, Inc. v. Forman.$^{44}$ Here again the Court was tasked to determine whether the transactions in question constituted securities transactions. In this case, the Court concluded that these were not securities transactions. ${ }^{45}$

United Housing involved a co-op housing complex that was selling "stock shares" in exchange for leasing space in one of the co-op's housing units. In the course of their tenancy, the plaintiff's alleged that the housing co-op neglected to disclose annual rent increases. ${ }^{46}$ The plaintiff's alleged that because their interests in the housing co-op was evidenced by purchasing shares of stock, that the interests in question were securities transactions. $^{47}$

The Court, however, disagreed with the plaintiff's characterization. ${ }^{48}$ Instead, in spite of the co-op interests being referred to as "stock" shares, the Court focused on the transaction's economic substance

\footnotetext{
${ }^{43}$ See id. at 299.

${ }^{44}$ United Hous. Found., Inc., v. Forman, 421 U.S. 837 (1975).

${ }^{45} \mathrm{Id}$.

${ }^{46} \mathrm{Id}$.

${ }^{47} \mathrm{Id}$. at 839 .

${ }^{48} \mathrm{Id}$. at 848 .
} 
and found that the interests in the housing units were NOT securities transactions. ${ }^{49}$ In arriving at its conclusions, the court focused on the economic substance of these so called "shares." The court's analysis revolved around comparing these so called "stock shares" to the typical characteristics found in a share of stock.$^{50}$ In that regard the court noted that the United Housing "shares of stock" did not have any of the typical characteristics found in a share of stock - namely the payment of dividends, the appreciation in value, or the exercise of voting rights - the characteristics commensurate with typical shares of stock. ${ }^{51}$ When distilled down to its essence, all that came with the ownership in the co-op's "shares" of stock was the right to occupy a specified unit in the housing's co-op. In substance, this ownership - in spite of being referred to as "shares of stock," were not deemed to be securities transactions. The focus on these transactions' economic substance is what guided the analysis regardless of how the transactions were referred to in form.

\section{Koskot - Ponzi Schemes - the "Common Enterprise" and Efforts of Others}

As will always be the case, the outer limits of a law's reach is going to be tested as the creative minds of the nefarious are often at work. Those that wish to skirt the securities law's long reach will be thoughtful in how they structure their transactions in attempts not to come within the purview of the securities law's regulatory regime. ${ }^{52}$ Conversely, the Securities and Exchange Commission will advocate for broad and expansive interpretations to reach transactions where investors are or are potentially being exploited. One such case that illustrates this idea is SEC v. Koskot Interplanetary. ${ }^{53}$

Koskot put at issue the outer limits of the Howey Test's third element, which is the requirement that the profits from the enterprise be

\footnotetext{
${ }^{49} I d$.

${ }^{50} \mathrm{Id}$. at $838-39$.

${ }^{51} I d$.

${ }^{52}$ Crypto Currencies and so-called "Digital Assets" have been under much scrutiny as the SEC has been watching this area closely and have repeatedly concluded that transactions involving these currencies have constituted securities transactions in spite of efforts to characterize them as something else. See Robert Crea, Anthony Nolan \& Eden Rohrer, Metamorphosis: Digital Assets and the U.S. Securities Laws, HARV. L. SCH. F. ON CORP. GOVERNANCE (2018), https://corpgov.law.harvard.edu/2018/07/07/metamorphosis-digital-assetsand-the-u-s-securities-laws/ [https://perma.cc/8TDH-AL25].

${ }^{53}$ See SEC v. Koscot Interplanetary, Inc., 497 F.2d 473 (1974).
} 
derived "solely from the efforts of others. ${ }^{54 "}$ "The narrow inquiry in Koskot was the question of whether this element is still satisfied when the investors in question, instead of being completely passive, do in fact take some role in the enterprise's profit-making endeavors. Called into question was to what extent could the investors be involved in the enterprise and still be able to maintain the transaction's legal status as a securities transaction. ${ }^{55}$

Koskot involved the now familiar business model of multi-level marketing schemes where the goal is to recruit others to join the enterprise and likewise purchase, use and or sell the enterprise's products. ${ }^{56}$ Koskot would recruit new members via a tightly scripted and orchestrated approach referred to as the "curiosity approach" multilevel marketing enterprises. Current members attempt to recruit new members by approaching friends, colleagues, even strangers and telling them they have a business opportunity that they might find interesting. But they don't tell the prospect what the opportunity is. ${ }^{58}$ The prospect shows up at the designated meeting spot, usually a member's home or some rented space for larger meeting, and in a tightly scripted fashion the meeting commences with the meeting's sole purpose being to convince prospects to join the enterprise so that they likewise will use the products, sell the products, and will recruit more members themselves to do the same. ${ }^{59}$ Earlier members get credit for recruiting later members. Earlier members also get credit for the products and services that members of their "down line" both use and sell. ${ }^{60}$

Were the Transactions in Question Securities?

Here, in Koskot, the securities question revolved around the Howey test's third element - that element being that the profits must be derived "solely" from the efforts of others. The issue here and the dilemma that the Court's wrestled with was the fact that those seeking to be deemed investors, i.e. Koskot's members, were also actively involved with meeting, and recruiting new members. ${ }^{61}$ Also, the members were the ones who hosted the recruiting meetings to which the prospects were invited. ${ }^{62}$ Again, these meetings were tightly scripted - the goal of which was to show outward trappings of wealth and success. ${ }^{63}$ The meeting might involve a

${ }^{54} I d$. at 479 .

${ }^{55} \mathrm{Id}$.

${ }^{56}$ Marketing Schools, Multi-Level Marketing: Explore the Strategy of

Multi-Level Marketing, MARKETINGSCHOOLS.ORG, https://www.marketing-schools.org/types-of-marketing/multi-levelmarketing/\#section [https://perma.cc/AWX6-LPPR] (last updated Nov. 23, 2020).

${ }^{57}$ Koscot Interplanetary, 497 F.2d at 476.

${ }^{58} \mathrm{Id}$.

${ }^{59} \mathrm{Id}$.

${ }^{60} \mathrm{Id}$.

${ }^{61}$ See id. at 485.

${ }^{62} \mathrm{Id}$. at 476.

${ }^{63} \mathrm{Id}$. at 485 . 
very high up member in the Koskot organization showing up at the meeting in a nice new car. Cadillacs were the suggested car of choice to show the outward trappings of wealth and success. ${ }^{64}$ The meeting's whole tone and tenor would be to get prospects excited about the opportunity to likewise achieve similar levels of wealth and success. ${ }^{65}$

Because the members did take an active role in recruiting new members, the court had to wrestle with how such member involvement reconciled with the element that profits were to be derived solely from the efforts of others. Here, the members clearly had some involvement with the endeavor. Hosting these meetings were integral to the enterprise's success. So - what impact did these member's involvement have on the Howey test's third element? The element speaking to the fact that profits were to be derived "solely" from the efforts of others.

The Court resolved this dilemma by expanding how the third element was to be interpreted and applied. In its reasoning, the Court stated, "contrary to the view of the district court, we need not feel compelled to follow the 'solely from the efforts of others' test literally. Nowhere in the opinion does the Supreme Court characterize the nature of the 'efforts' that would render a promotional scheme beyond the pale of the definition of an investment contract. . " role that the scripted meetings played in the Koskot enterprise by reasoning that such a role was not the type of "effort" that should negate the finding of a securities transaction. The Court narrowed what constituted effort to those "undeniably significant" efforts; those efforts that were managerial in nature ${ }^{67}$ Because the recruiting meetings were tightly scripted and didn't involve any strategic thought, planning, analysis, etc., the Court concluded that the investor's roles in hosting the meetings were merely "ministerial" and therefore should not be deemed as significant enough to negate the Howey Test's third element. ${ }^{68}$ Accordingly, the Court found the Koskot multi-level marketing scheme to be a security. ${ }^{69}$

The Takeaway

The takeaway from the Koskot case is an appreciation for how courts grapple with securities law issues. Courts will flex toward broader interpretations rather than narrow ones. Findings will often be based on the economic substance. ${ }^{70}$ Here, in Koskot's case it is reasonable to conclude that the Court had issues with how new members were lured into the Koskot organization. The promise of riches, the tightly scripted meeting process, and the intentional displays of wealth; all were designed to

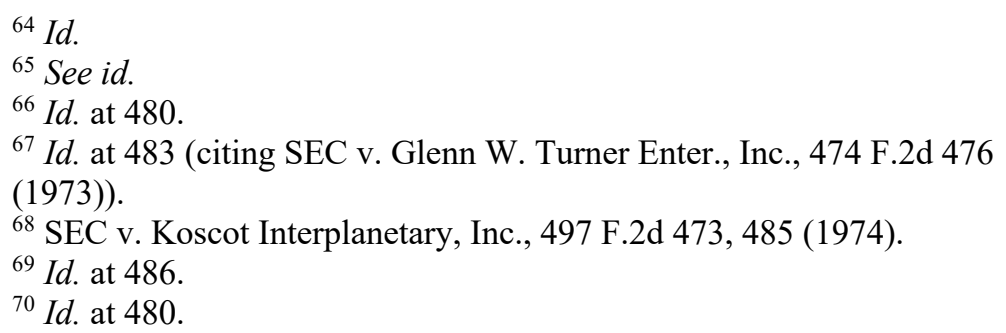


manipulate the prospects into joining the Koskot enterprise. Though not explicitly stated in the opinion, one could conclude that Koskot's manipulative recruiting tactics played into the Court's findings. Note in the Court's final comments, "we merely endorse a test which is resilient enough to encompass the egregious promotional scheme purveyed by Koskot." "71 Again, the asymmetrical nature of the relationship versus two sides being on equal footing. The Court took an expansive view in this case, but it did so to get at a scheme that the Court likely felt was taking advantage of people and preying on their susceptibility to the promises of wealth and riches. ${ }^{72}$

\section{III.THE SECURITIES ISSUANCE PROCESS}

History demonstrates that dorm rooms have been the birthplace of several of the world's largest businesses: Mark Zuckerberg and several classmates founded Facebook while at Harvard: ${ }^{73}$ Google's creation by Larry Page and Sergey Brin while at Stanford $;{ }^{74}$ Michael Dell's start-up of Dell Computer resulted from selling computers from his dorm room while a student at the University of Texas in Austin $;{ }^{75}$ Uber, Airbnb, and others ${ }^{76}$ are recent examples of very successful businesses that have experienced profound periods of growth. Sooner or later, every highly successful startup company will need additional capital to finance their growth. These companies create the jobs that enable large populations to feed, house, and clothe their children. The taxes generated from these businesses finance public education, healthcare, and other necessary services provided by governmental institutions. We will now explore some of the legal requirements involved with raising capital.

\section{Registration Process}

An initial public offering (IPO) is the process by which a company offers the company's stock shares to the public. Administratively, the IPO process involves a company completing what is referred to as a Registration Statement. ${ }^{77}$ The company files the Registration Statement with the

${ }^{71} I d$. at 486 .

${ }^{72}$ See id.

${ }^{73}$ E.g., Ben Mezrich, The Accidental Billionaires: The FOUNDING OF FACEBOOK (2009); ROGER MCNAMEE, ZUCKED (2019).

${ }^{74}$ See generally STEVEn LeVy, In THE Plex (2011).

${ }^{75}$ See generally Michael Dell, Direct FROM Dell: StRATEgies that REVOLUTIONIZED AN INDUSTRY (2006).

${ }^{76}$ See generally Brad StOne, The UpStARTS: Uber, AirbnB, AND the

BATTLE FOR THE NEW SiLICON VALLEY (2017).

77 The Office of Investor Education and Advocacy, Investor Bulletin: Investing in an IPO, INVESTOR.GOV (Feb. 25, 2013), https://www.investor.gov/introduction-investing/general-resources/newsalerts/alerts-bulletins/investor-bulletins-17 [https://perma.cc/6GPN2V3Y]. 
Securities and Exchange Commission. ${ }^{78}$ The Registration Statement contains a penumbra of required information about the company's business, finances, operations, and management. ${ }^{79}$ Staff at the Securities and Exchange Commission review the Registration Statement. ${ }^{80}$ Once they are satisfied that the Registration Statement contains all the necessary disclosures, it declares the Registration Statement effective which then allows the issuer to offer its shares to the public. ${ }^{81}$ This section takes a look at various aspects of this public offering process. The decision to take a company public is a seminal event in any company's life. For companies that consider this move carefully, the registration process has many layers to it.

\section{The Business Decision}

Before the first words of a Registration statement are drafted, those companies that are thoughtful about the process will first go through much internal assessment to determine whether going public is the right decision for them as the implications of doing so are far reaching. ${ }^{82}$ Companies that are circumspect will go through a deliberative process that considers what things will look like once they are on the other side of the public offering and are operating as a publicly traded company. ${ }^{83}$ And then they will work backwards and see what needs to happen administratively, logistically, operationally, etc., to get their company ready to go through the public offering process and operate as a publicly traded company. ${ }^{84}$ The decision making process in taking a company public is a paper topic unto itself. Here, some of the high-level aspects involved are touched upon.

Public vs. Private - Everyone Literally in Your Business Now

The first and perhaps the most invasive aspect of going public is the disclosure regime under which the company will be operating once the company becomes publicly owned. The process of going public along with operating on an ongoing basis as a publicly traded company means that the company is now required to open up and share its inner workings and lay bare for all the public to examine, critique, scrutinize, etc. ${ }^{85}$ This disclosure regime is a cost of doing business. Part of the cost of gaining access to the public markets and the billions of dollars that can be accessed there is disclosing all the material financial and business aspects of your company

\footnotetext{
${ }^{78} I d$.

${ }^{79} \mathrm{Id}$.

${ }^{80} \mathrm{Id}$.

${ }^{81} \mathrm{Id}$.

82 See Larry D. Soderquist \& Theresa Gabaldon, Securities

REGULATION 24-31 (9th ed. 2018).

${ }^{83} \mathrm{Id}$.

${ }^{84} \mathrm{Id}$.

${ }^{85} \mathrm{Id}$.
} 
on an ongoing basis. ${ }^{86}$ Companies are legally required to tell the investing public "the good the bad and the ugly" regarding their company - warts and all. This disclosure regime can take some getting used to. For some companies it can be a real challenge; especially with the initial public offering where the issuer has its first experience with disclosing the inner workings of its operations to the public. Part of the disclosure regime requires disclosing to the public all the bad things that could happen to the issuer. The SEC's disclosure regime has a specific section in the Registration Statement for this which is referred to as the "Risk Factors." 87 Item 105 of Regulation $\mathrm{S}-\mathrm{K}$ is the section that lays out the disclosure requirements for Risk Factors. With respect to this section, the disclosure requirements state, "Where appropriate, provide under the caption 'Risk Factors' a discussion of the material factors that make an investment in the. . offering speculative or risky. . .Do not present risks that could apply to any issuer or any offering. Explain how the risk affects the issuer or the securities being offered. . ." 88

The SEC's disclosure regime requires the issuing company to understand and appreciate that it will be opening its doors, drawers, and closets to the public for scrutiny, examination, and criticism. Management needs to have a full understanding and appreciation for this invasive part of the process that is ongoing and unyielding.

Getting the Corporate House in Order

From a corporate governance standpoint, operating as a publicly traded company versus a privately held one is different as well. The issuing company has to make sure that it is situated both legally and organizationally to operate as a publicly traded company. From a legal standpoint, the company more than likely will have to reconsider its capital structure. If the company's capital raising path has been like many, then prior to seeking access to the public markets, the company may have undergone a number of financing options such as private offerings to friends and family, offerings to what are referred to as "Angel Investors", and possibly even a number of offering rounds to venture capitalists. ${ }^{89}$

${ }^{86}$ The SEC has a robust disclosure regime. For example, companies offering shares to the public for the first time are required to use what is referred to as Form S-1. Key sections to the prospectus which is the disclosure document within the S-1 are the Prospectus Summary, Risk Factors, Use of Proceeds, Management's Discussion and Analysis, and Management. Mandated guidance on what each of these sections should contain is set out in Regulation S-K. Thus, Form S-1 and Regulation S-K work together in laying out what and how company information is to be disclosed in the company's prospectus. See generally Regulation S-K, 17 C.F.R $\S \S 229.10-229.1406$.

8717 C.F.R. § 229.105; see also 17 C.F.R. § 229.503.

8817 C.F.R. § 229.105; see also 17 C.F.R. § 229.503.

${ }^{89} \mathrm{See}$ Therese H. MAynard, Dana M. WARren \& Shannon Trevino, Business PlanNing: FinanCing the StaRT-Up Business and Venture 
Assuming this is the case, then the company must make sure that it restructures its capital prior to undertaking the public offering process. ${ }^{90}$

Often times, private offerings don't involve the common stock that is typically used in public offerings. ${ }^{91}$ But the stock issued to these private investors may have been various forms of preferred stock. ${ }^{92}$ Preferred stock is any stock that has a characteristic or feature that gives the preferred stock holder a right, preference, or privilege that is superior to the rights, preferences, or privileges ascribed to the common shares. ${ }^{93}$ For example, the preferred stock holders in a given company may have what is referred to as a "liquidation preference." "94 A liquidation preference is a stock preference that gives the Preferred Shareholder some type of superior right to the common shareholders in the event that the company decides to liquidate ${ }^{95}$ i.e. sell all of its assets by converting those assets to cash and then splitting up the proceeds amongst its shareholders. ${ }^{96}$ Preferred stock with a liquidation preference might have the right to receive say $\$ 1,000$ per share of those liquidated assets before the common shareholders receive anything. ${ }^{97}$ Accordingly, addressing the aspect of preferred stock holders is important, since any contractual rights that these preferred shareholders have may be disruptive to the public offering process if those contractual rights aren't properly addressed.

Fortunately, venture capitalists are invariably in the venture capital business to realize profitable returns on their investments. Taking a company public is one of the most profitable ways that preferred shareholders can realize a return on their investment. Accordingly, along with whatever rights, preferences, and privileges that may have been ascribed to a share of preferred stock, those preferred shareholders will likely receive such contractual rights as the right to convert their preferred

CAPITAL FINANCING 445 (3d ed. 2018) (as a general primer on capital raising).

${ }^{90}$ SODERQUisT \& GABALDON, supra note 82 , at 38 .

${ }^{91}$ Preferred Shares as the financing vehicle of choice is laid out in some detail in Business Law casebooks and other materials. For a full discussion on preferred stock and how it is used in financing deals see MAYNARD, supra note 89, at 517.

${ }^{92} \mathrm{Id}$. at 517.

${ }^{93} \mathrm{Id}$. at $518-19$

${ }^{94} I d$. at 531.

${ }^{95}$ Id. See also Lawrence J. Trautman, Anthony J. Luppino \& Malika S. Simmons, Some Key Things U.S. Entrepreneurs Need to Know About the Law and Lawyers, 46 TEX. J. Bus. L. 155 (2016).

${ }^{96}$ Aaron Kellner, See What You Need to Know About Liquidation Preferences, SEED InVEST (July 31, 2018), https://www.seedinvest.com/blog/startup-investing/liquidation-preferences [https://perma.cc/U63T-J2GP].

${ }^{97}$ Actual liquidation preferences are usually more involved than the examples used here. 
shares into common shares in the event the company goes public. ${ }^{98}$ Alternatively, the preferred shares may be offered registration rights which would give the preferred shareholder the contractual right of having their preferred shares registered and included in the public offering. ${ }^{99}$ Again, a thoughtful company will issue preferred shares, at least considering the prospect that the company may do a public offering at some point down the road and will take that contingency into consideration by providing for contractual provisions ascribed to the preferred shares that call for conversion and or registration rights.

Structuring the Public Offering

Other implications involved in a company offering its shares to the public is the matter of control. Understand that each share of common stock issued to the public represents a sliver of company ownership. The more shares issued to the public, the greater the proportion of that company being owned by public shareholders. Again, a thoughtful public offering involves the company planning for this contingency. One thing to appreciate about the state corporate codes that reside in our fifty state jurisdictions is that these corporate codes allow for flexibility, creativity, and innovation which is limited only by the imaginations of its crafters. In the events leading up to a public offering, the company will restructure its capital to make sure that some things remain intact even after the company goes public. ${ }^{100}$ For example, the company may want to ensure ultimate company ownership and control remains vested in a finite number of shareholders; perhaps the founding shareholders or the shareholders who invested in the company in

${ }^{98}$ Therese H. MAYNARD, DANA M. WARREN \& SHANNON TREVINO, Business PlanNing: FinanCING THE START-Up BusinesS AND VENTURE CAPITAL FINANCING 566 (3d ed. 2018). The conversion right allows the preferred shareholder to participate in the company's upside. A company offering its shares to the public would be considered upside.

${ }^{99}$ See Yokum, What Are Piggyback Registration Rights?, STARTUP COMPANY LAWYER (Aug. 15, 2007), http://www.startupcompanylawyer.com/2007/08/15/what-are-piggybackregistration-rights/ [https://perma.cc/MG6D-BPU9]. These rights are referred to as piggyback registration rights. Piggyback registration rights entitle investors to register their shares of common stock whenever the company conducts a public offering, subject to certain exceptions. Unlike demand rights, piggyback rights do not entitle investors to require a company to conduct a public offering but simply allow them to include shares in a registration that is initiated by the company. Piggyback registration rights typically are not particularly disruptive (other than the effort involved in contact investors with piggyback right to solicit their participation in a registration) and do not require the special effort of demand registrations. Companies usually bear the cost of investors exercising piggyback rights.

${ }^{100}$ Investor Bulletin: Investing in an IPO, INVESTOR.GOV (Feb. 25, 2013), https://www.investor.gov/introduction-investing/general-resources/newsalerts/alerts-bulletins/investor-bulletins-17 [https://perma.cc/4MLBPWSN]. 
the early stages. ${ }^{101}$ To achieve such a result, the company may amend its charter - thereby creating different classes of stock - each with varied voting rights. ${ }^{102}$ "Class A Common" for example may be created and issued to a select number of founders. These shares could be given a stock right of ten votes per share whereas the common shares offered to the public would only have one vote per share. This tiered approach was the capital structure that United Parcel Service set up as a pre-cursor to its initial public offering occurring back in $1999 .{ }^{103}$ By creating alternate classes of stock with varied voting rights, UPS's founding shareholders were able to access the public markets while still maintaining operational and voting control over the company by issuing tiered classes of stock with varied voting rights. All of these steps are legal. The only caveat being that the company must disclose these machinations in its offering documents so that the investing public is aware of what they are getting - (and not getting) by virtue of their investment in the company. ${ }^{104}$

\section{The "Gun Jumping" Rules of Section 5}

The premise upon which the securities laws are built are to protect investors through timely and appropriate disclosure as it relates to issuing, selling, buying, or exchange of securities. The idea is that investors or potential investors are making informed decisions about the companies in which they are investing. This disclosure regime is robust in the context of a company offering its shares publicly for the first time - (i.e. the initial public offering).

The ' 33 Act's Section 5

The '33 Act's Section 5 is perhaps the Act's most analytically challenging section. Reading and properly interpreting Section 5 requires an appreciation for the '33 Act's idiosyncratic and layered nature. Such drafting was intentional on the part of its authors who penned the Act's first versions back in $1933 .{ }^{105}$

Reading and parsing through the ' 33 Act's Section 5 is a rigorous endeavor. Once dissected however, its mandates are fairly straightforward. Again, in keeping with this recurring theme of required disclosure as the

\footnotetext{
${ }^{101} \mathrm{Id}$.

102 See SODERQUIST \& GABALDON, supra note 82; see also Investor Bulletin: Investing in an IPO, supra note 100 (explaining dual-class common stock).

${ }^{103}$ United Parcel Serv. Amendment No. 4 to Form S-1 7 (Form S-1/A)

(Nov. 5, 1999). UPS created Class A-1, Class A-2, and Class A-3

Common Stock. Each of these classes had voting rights of 10 votes per share. The Class B common shares that were being offered to the public had voting rights of one vote per share. The Class A Common Shares represented $90 \%$ of the total outstanding shares and $99 \%$ of the voting control. Thus, UPS raised over $\$ 5$ billion in its public offering but only gave up $1 \%$ of its voting control as a result. ${ }^{104} I d$.

${ }^{105}$ See Soderquist \& GABALDON supra note 82 , at 3-4.
} 
pre-cursor to offering, buying, or selling securities, Section 5 carries that theme and requires as follows:

Section 5 delineates into three discrete time periods in relation to the timing of a public offering: the pre-filing period, the waiting period, and the post-effective period. ${ }^{106}$

1. The Pre-filing Period: The first defining period that implicates Section 5's mandates is the pre-filing period. This is the period leading up to but prior to a company filing its registration statement. ${ }^{107}$ During the prefiling period, the company is prohibited from both offering to sell and selling its securities. ${ }^{108}$ Again, the idea here is that the SEC does not want companies percolating the prospect of buying into some new venture without the investing public having the benefit of and access to a vetted document that has the prescribed business and financial disclosures regarding the company. So, companies are prohibited from making any offers to the public prior to filing their registration statement with the SEC. ${ }^{109}$

\section{The '33 Act's Hidden Traps}

Although this prohibition seems clear enough, the challenge comes in understanding the ' 33 Act's definitional traps. As alluded to earlier in this writing, securities law concepts tend to be interpreted both liberally and broadly. ${ }^{110}$ The ' 33 Act's reach is expansive when applying or interpreting its provisions. Section 5 is no exception. A key aspect regarding the prohibition against a company "offering" to sell its securities before a registration statement is filed is the ' 33 Act's broad definition ascribed to an "offer." Section 5 takes what we might have understood to be a typical offer and takes it to another level. The ' 33 Act defines an offer as, “. . . every attempt to offer to dispose of, or solicitation of an offer to buy a security or interest in a security for value ...."111 This broad definition puts companies in a precarious position when it starts to consider the proposition of taking its shares public. In addition to all the internal housekeeping matters discussed earlier, in the run up to offering its securities for sale, the company must also now be aware and sensitive to its "outward manifestations" to the public.

The use of the term "outward manifestations" is intentional to stress the fact that the SEC interprets the idea of an "offer" broadly and therefore a company should take care not to trip that wire as the consequences for

${ }^{106}$ These three periods are derived from the filing and disclosure mandates laid out in the Securities Act's Section 5. They are also described well in academic casebooks. E.g., Alan A. PALMiter, EXAMPLES \& EXPLANATIONS FOR SECURITIES REGULATION 153 (7th ed. 2017). ${ }^{107} I d$.

${ }^{108}$ Securities Act of $1933 \S 5(c), 15$ U.S.C. $\S 77 \mathrm{e}$.

${ }^{109} \mathrm{Id}$.

${ }^{110}$ See SEC v. Koscot Interplanetary, Inc., 497 F.2d 473, 486 (1974).

${ }^{111}$ Securities Act of 1933 § 2(a)(3), 15 U.S.C. $\S 77 b$. 
doing so can be dire. ${ }^{112}$ One of the main consequences of running afoul of the SEC's "gun jumping" rules is that the SEC has the power and the discretion of delaying the effective date of a company's registration statement which has the intended effect of delaying the date on which a company can sell its shares to the public. ${ }^{113}$ For some companies, going public is time sensitive, where the missed window may scuttle the whole endeavor. For others, it may be a minor inconvenience. All things being equal, given the stakes involved and the millions of dollars in play, companies are well advised to operate within Section 5's gun jumping confines. Accordingly, offers to sell securities or selling the company's securities are prohibited during the pre-filing period. ${ }^{114}$

2. The Waiting Period - The waiting period is the period after the company has filed the registration statement and is now waiting for the SEC to declare the registration statement effective. ${ }^{115}$ Understand, the company now has a draft of its registration statement on file with the SEC. A draft of a document that provides information regarding the company such as historical profit and loss information, information about the business and its operations, information about the company's management, and of course those vaunted "risk factors" alluded to earlier. ${ }^{116}$ With this information regarding the company prepared and on file with the SEC, the company can now make offers. But again, the manner in which a company can make these offers is regulated and restricted. The company is limited to making oral offers, and any written offers must be accompanied by the SEC compliant prospectus that is a part of the materials filed in the registration statement. ${ }^{117}$ Understand that the company prepared this information pursuant to a specific set of rules and regulations that mandates with some specificity the information that must comprise the registration statement's contents. ${ }^{118}$

Again, the idea is to control the information being disseminated to potential investors. ${ }^{119}$ The SEC wants to be sure that information is complete, thorough, and accurate within material limits. The information contained in the SEC compliant prospectus is the information that the SEC wants investors to have access to prior to making their decision to invest. ${ }^{120}$

${ }^{112}$ See Publ'n of Info. Prior to or After the Effective Date of a Registration Statement, Securities Act of 1933 Release No. 3844 (Oct. 8, 1957).

${ }^{113}$ See Brian Johnston, Don't Jump The Gun - Pre-IPO Considerations, GiLMARTIN GROUP (Dec. 6, 2019), https://gilmartinir.com/dont-jump-thegun-pre-ipo-considerations/ [https://perma.cc/L8R4-MSYD].

${ }^{114}$ Securities Act of $1933 \S 5(c), 15$ U.S.C. $\S 77$ e.

${ }^{115}$ PALMITER, supra note 106, at 153.

${ }^{116}$ United Parcel Serv., Amendment No. 4 to Form S-1 10 (Form S-1/A) (Nov. 5, 1999).

${ }^{117}$ Securities Act of $1933 \S 5(a), 15$ U.S.C. $§ 77$ e.

${ }^{118}$ For example, Regulation S-K gives comprehensive guidance on how information in form S-1 and other forms should be disclosed.

${ }^{119}$ See generally SODERQUIST \& GABALDON, supra note 82.

${ }^{120}$ Securities Act of $1933 \S 5(\mathrm{~b})(1)-(2), 15$ U.S.C. $\S 77 \mathrm{e}$. 
Accordingly, all offers made during the waiting period must be accompanied or preceded by an SEC compliant prospectus. ${ }^{121}$

It is very important to note although companies may make offers to buy their securities, during the waiting period, companies are nonetheless prohibited from making sales during the waiting period. ${ }^{122}$ "Sales" cannot occur until the SEC declares the registration statement effective. ${ }^{123}$ During the waiting period, issuing companies get what are referred to as "indications of interest." 224 With these "indications of interest" - the company, through its underwriters, will approach a potential investor. ${ }^{125}$ Investors tend to be high net worth individuals such as a Jerry Jones or an Oprah Winfrey, or institutional investors such as mutual fund companies, pension fund companies, or insurance companies looking to diversify their portfolios. ${ }^{126}$ If a potential investor wants to participate in the IPO, the investor will respond with, "Put me down for X shares." 127 This is the investor indicating his interest. Mind you, although this is not a contractual obligation per se, an investor's failure to follow through on their "indication of interest" usually results in not being approached the next time an IPO comes available. Also, word travels fast in these circles which could mean that this potential investor may not receive calls down the road from underwriters regarding future or pending IPOs.

Again, the idea behind these prohibitions is investor protection. Presumably, when a registration statement is filed, it is an unfinished document. The waiting period is the time where the SEC's Division of Corporate Finance reviews that registration statement against the SEC's disclosure mandates to ensure that the company has disclosed all the information that the company is required to disclose and done so in accordance with the SEC's mandates. ${ }^{128}$ This review function is typically performed by an SEC staff attorney who works within the Division of Corporate Finance. That person could easily be someone one or two years out of law school, or it could be a former law firm partner who has grown tired of the 2,000 annual billable hour requirement and is seeking the more normal hours that comes with working for the federal government. ${ }^{129}$

${ }^{121}$ Securities Act of $1933 \S 5(\mathrm{~b})(2), 15$ U.S.C. $\$ 77 \mathrm{e}$.

${ }^{122}$ Securities Act of $1933 \S 5(\mathrm{a})(1)-(2), 15$ U.S.C. $\S 77 \mathrm{e}$. Sales are restricted until the SEC declares the registration statement effective. ${ }^{123} \mathrm{Id}$.

${ }^{124}$ Investor Bulletin: Investing in an IPO, supra note 100.

${ }^{125}$ E.g., PALMITER, supra note 106, at 162.

${ }^{126}$ Investor Bulletin: Investing in an IPO, supra note 100.

${ }^{127} \mathrm{Id}$.

${ }^{128}$ Id. Specifically, refer to the section titled "What is an IPO."

${ }^{129}$ Here, the author is drawing upon his own experience with the SEC. Though dated, during the summer of 1996, the author interned at the SEC's office in Washington D.C. and met first hand, former law firm partners who expressed their preference for working at the SEC in part due to the more regular work hours. The author also met Staff Attorneys 
In any event, this SEC staff attorney will review the registration statement's prospectus and will write comment letters on that registration statement. ${ }^{130}$ These comment letters are simply things that the examiner has noted as needing more disclosure, more detail, more clarification, etc. The exchange of comment letters can go back and forth between the SEC and the company a number of times before all comments are cleared. ${ }^{131}$ Once the SEC is satisfied with the registration statement's contents, then the SEC will declare the registration statement effective and the company now can consummate all the "indications of interest" that it collected during the waiting period. ${ }^{132}$

3. The Post Effective Period - The point after which the SEC declares the registration statement "effective" marks the Post Effective Period. The company can now both offer and sell its securities. ${ }^{133}$ Additionally, all the "indications of interest" the company recorded during the waiting period can now be finalized with the investors forwarding payment in exchange for shares. ${ }^{134}$ SEC protocols are still in effect, however. The rules require that prior to any sales transaction being completed, the consummation of the sales process again must be preceded by or accompany the now effective registration statement. ${ }^{135}$ The recurring refrain here being that the investor's decision is an informed one. Over the years, the SEC has made compliance with this mandate much easier. ${ }^{136}$ With technology now making information readily accessible, the SEC has deemed this requirement as being met once the registration statement has been declared effective. ${ }^{137}$ The SEC has a database referred to as Electronica Data Gather Analysis and Retrieval (EDGAR). All public filings are stored in the SEC's EDGAR database and can be accessed by anyone having access to a computer and an internet connection. ${ }^{138}$ Because

who worked in the same division who were either recent graduates or were fairly new attorneys who had made a move to the SEC early in their careers.

${ }^{130}$ Investor Bulletin: Investing in an IPO, INVESTOR.GOV (Feb. 25, 2013), https://www.investor.gov/introduction-investing/general-resources/newsalerts/alerts-bulletins/investor-bulletins-17 [https://perma.cc/4MLBPWSN].

${ }^{131} I d$.

${ }^{132} I d$.

${ }^{133}$ Securities Act of $1933 \S 5(\mathrm{a}), 15$ U.S.C. $\S 77$ e.

${ }^{134}$ Investor Bulletin: Investing in an IPO, supra note 100.

135 Securities Act of $1933 \S 5(\mathrm{~b})(2), 15$ U.S.C. $\S 77 \mathrm{e}$.

136 See 17 C.F.R. $\S 230.172$ (b) (2021). In 2005, the SEC passed a number of reforms that eased some of the regulatory burden on issuers. One of those lightened regulatory burdens was the requirement that investors receive a prospectus prior to consummating a securities sale. The SEC implemented the "Access Equals Delivery" protocol which is codified in Securities Act Rule 172b.

137 See 17 C.F.R. § 230.172(b) (2021).

138 The EDGAR database can be accessed through SEC.gov. 
of this accessibility, once the SEC declares the registration statement effective and that effective registration statement is available on the SEC's EDGAR system that is all that is required to meet the post effective period protocols. $^{139}$

This writing provides a distilled version as to how the SEC's gun jumping rules work. Again, Section 5's underlying premise is intuitive and straightforward. But the traps for the unenlightened stem from the SEC's broad definitions as to what constitutes an offer. Taking heed to these definitional traps and staying within its boundaries is what is key to keeping a company from running afoul of the SEC's gun jumping rules.

\section{Exempt Transactions}

The large majority of businesses out there are too small and don't have a need to go through a full blown time intensive expensive registered offering process. ${ }^{140}$ But these businesses nonetheless need capital to operate with issuing stock being one of the most effective ways to get access to that needed capital. ${ }^{141}$ Thus enters what is referred to as the private exemption, or private offering. A maxim in the securities world and one that is important to remember is - "Any time securities are bought or sold, those securities must either be registered or be bought or sold under an applicable exemption." ${ }^{\prime 42}$ This general rule is important to understand the practices that occur with companies and their quest at raising capital through issuing stock. As mentioned earlier, raising capital through a registered offering is not a viable option for most companies. Thus, the private offering is the backstop and the means by which smaller companies gain access to much needed capital. ${ }^{143}$

The Private Offering Regime

The private offering regulatory regime is complicated. This is an understatement. Here the attempt is made to give a working overview of how this space works. The best way to understand how the private offering regime works is to understand the underlying rationale for the SEC

13917 C.F.R. § 230.172(b) (2021).

${ }^{140}$ See SEC Harmonizes and Improves "Patchwork" Exempt Offering

Framework, U.S. SEC. AND EXCH. COMM'N (Nov. 2, 2020), https://www.sec.gov/news/press-release/2020-273 [https://perma.cc/8V22$7 \mathrm{HWM}]$. "The registration process generally is designed for larger companies with substantial resources. As a result, many entrepreneurs and emerging businesses raise capital by selling securities in reliance on an offering exemption ...."

${ }^{141}$ See id.

${ }^{142}$ See id. "A core component of our federal regulatory regime is the requirement that all securities offerings be registered with the Commission or qualify for an exemption from registration ...."

${ }^{143}$ See id. "The registration process generally is designed for larger companies with substantial resources. As a result, many entrepreneurs and emerging businesses raise capital by selling securities in reliance on an offering exemption ...." 
allowing for situations where companies can offer securities without having to register them in the first place. The underlying rationale from the SEC's point in those situations where the risk of investors being harmed is not high, the SEC is not going to task a company to go through the time consuming and expensive process of requiring the company to register its securities prior to offering them. ${ }^{144}$

Accordingly, when the risk of investor harm is low, or the risk of investor exposure is low, the SEC will allow companies to issue its stock without having to register them. It is helpful to keep these underlying principles in mind as the various exemptions are discussed.

\section{The Common Private Offering Exemptions}

\section{Net Income}

The "Reg. D" Exemption - Offerings to High Net Worth or High

\section{Individuals-}

From a statistical stand point, the most commonly used private exemptions are the ones that fall under what is referred to as Regulation D. ${ }^{145}$ Regulation D consists of Rules 500-508. ${ }^{146}$ Nested within those rules are voluminous amounts of information laying out how the Regulation D exemptions work. The most common Regulation D exemption is the one that falls under Regulation D's Rule 506(b). ${ }^{147}$ This exemption provision allows companies to issue securities without having to register those securities if the investors in question are either accredited or the investor, "has such knowledge and experience in financial and business matters that he is capable of evaluating the merits and risks of the prospective investment, or the issuer reasonably believes immediately prior to making any sale that such purchaser comes within this description." D's Rule 501 provides the definition for accredited investors which includes the following:

a. Any natural person who had individual income in excess of $\$ 200,000$ in each of the two

${ }^{144}$ See id. "For many small and medium-sized business, our exempt offering framework is the only viable channel for raising capital."

${ }^{145} 15$ U.S.C. $\S 77(\mathrm{~d})$.

${ }^{146} \mathrm{Id}$.

${ }^{147} I d$. Regulation D: According to SEC data, there were over 15,500 initial Regulation D filings for up to $\$ 5$ million in fiscal years 2010 and 2011. In comparison, there were 8 qualified initial Regulation A offerings during this period. According to a recent report prepared for SEC, the median Regulation D offering was \$1 million from January 2009 through March 2011 and the overwhelming majority of Regulation D issuers have been issuing securities under Rule 506.20. See also U.S. Gov'T AcCountability OfF., GAO-12-839, SeCurities Regulation: Factors That May AfFect TRENDS in Regulation A OfFERIngs (2012). 14817 C.F.R. $\S 230.506$ (b)(2)(ii) (2021). 
most recent years or joint income with that person's spouse in excess of $\$ 300,000$ in each of those years and has a reasonable expectation of reaching the same income level in the current year. ${ }^{149}$

b. Any natural person whose individual net worth or joint net worth with that person's spouse, at the time of his purchase exceeds $\$ 1,000,000 .{ }^{150}$

c. Any director, executive officer, or general partner of the issuer of the securities being offered or sold, or any director, executive officer, or general partner of that issuer. ${ }^{151}$

There are additional accredited investor definitions related to entities as opposed to individuals. ${ }^{152}$ The ones noted above are the ones most relied upon when dealing with individuals and their accredited investor status. Those persons who are not accredited but nonetheless are considered "financially sophisticated" are referred to as "purchasers." Offerings under Rule 506(b) are limited to no more than 35 of these purchasers. ${ }^{154}$ The number of accredited investors that can participate, however, is unlimited. ${ }^{155}$ Again, the unlimited number of accredited investors is in keeping with the SEC's investor protection concerns. Because of their accredited investor status derived from either being wealthy, having a high income, making a lot of money, or having an executive level position within the company puts the investor in a position where the investor can fend for himself and therefore the SEC does not have to be concerned about the investor being taken advantage of.

Offers that Occur Entirely Within a Single State or Territory - The "3(a)(11)

Exemption"

Offerings that occur entirely within a single state or territory are likewise exempt from registration. This exemption is referred to as the "3(a)(11) Exemption" - which, of course, refers to Section 3(a)(11) of the '33 Act. ${ }^{156}$ Under the 3(a)(11) exemption, the issuer must be a resident of and doing business within that state or territory and the investors must

14917 C.F.R. $\S 230.501(\mathrm{a})(6)(2021)$.

${ }^{150} I d . \S 230.501(\mathrm{a})(5)$.

${ }^{151} I d . \S 230.501(\mathrm{a})(4)$.

${ }^{152}$ E.g., id. $\S 230.501(\mathrm{a})(1)-(3),(7)-(8)$.

15317 C.F.R. $\S 230.506($ b)(2)(ii) (2021).

${ }^{154} I d . \S 230.506(\mathrm{~b})(2)(\mathrm{i})$.

${ }^{155}$ See 17 C.F.R. § 230.501(e)(1)(iv) (2021) (regulation D’s Rule

$501(\mathrm{e})(1)(\mathrm{iv})$ specifically excludes accredited investors from the thirtyfive-purchaser cap set forth in Rule 506(b)). See also 17 C.F.R. § 230.506(b) (2021).

${ }^{156}$ Securities Act of 1933 § 3(a)(11); 15 U.S.C. § 77c. 
likewise be residents of that state or territory. ${ }^{157}$ Provided both of these criteria are met, the company can issue securities to these in-state investors with no limit as to how many investors can participate, no limit as to the offering size, and no limit as to how much any one investor can invest. ${ }^{158}$

Staying within the strictures of the 3(a)(11) exemption from the issuer's standpoint revolves around understanding what it means to be a "resident and doing business within that state." To give practitioners concrete guidelines to follow, the SEC promulgated Rules $147^{159}$ and 147A. ${ }^{160}$ These rules provide what are referred to as "safe harbor" provisions where - if explicitly followed, the issuer knows that it qualifies for the 3(a)(11) exemption. For example, what does it mean for a business to be a resident within a state or territory? Rule 147(c)(1) notes "the issuer shall be deemed to be a resident of the state or territory in which: it is incorporated... and it has its principal place of business if a corporation. . "161 Thus, the rule gives clear quantifiable guidelines -explaining how an issuer is deemed to be a resident. When the issuer is a corporation, being incorporated in that state, plus having your principal place of business in that state would be a clear indication of meeting 3(a)(11)'s residency requirement where the issuer is a corporation.

Likewise, regarding the question of what it means to be "doing business" within a specific state or territory. The idea principally is that the issuer has operations significant enough within that state or territory to be overseen, regulated, and held liable by state securities regulators if something runs afoul with respect to the issuer and the securities being issued. ${ }^{162}$ Again - The '33 Act's Section 3(a)(11) doesn't define what it means to be doing business within that state or territory, so Rule 147 again gives quantifiable guidelines.

Under Rule 147 c.2. For example, an issuer is deemed to be doing business within that state or territory if at least one of the following criteria have been met.

i. The issuer has derived at least $80 \%$ of its revenues from operations within that state.

${ }^{157} \mathrm{Id}$.

${ }^{158}$ Section 3(a)(11) makes no mention of offering size or investor qualification. The only stipulations are that the issue and the investors both be residents within that state or territory. Securities Act of $1933 \S$ 3(a)(11); 15 U.S.C. $\$ 77 \mathrm{c}$.

159 See 17 C.F.R. $§ 230.147$ (2021).

${ }^{160}$ See id. $\S 230.147 \mathrm{~A}$.

${ }^{161} I d . \S 230.147(\mathrm{c})(1)(\mathrm{i})-(\mathrm{ii})$.

${ }^{162}$ For a full discussion on the 3(a)(11) exemption and the corresponding Rule 147 and Rule 147A, see 17 C.F.R. $\S 200,230,239,240,270$, \& 275, and see also Exemptions to Facilitate Intrastate and Regional Securities Offerings, Securities Act of 1933 Release Nos. 33-10238, 34-79161 (Oct. 26, 2016), https://www.sec.gov/rules/final/2016/33-10238.pdf. [https://perma.cc/ZX4T-9JXB]. 
ii. At least $80 \%$ of those issuer's assets are located within that state;

iii. The issuer intends to use and uses $80 \%$ of the offering proceeds for in state operations; or

iv. A majority of the issuer's employees are based in such state or territory. ${ }^{163}$

The safe harbor criteria gives the issuer clear quantifiable guidelines where the issuer knows with certainty that it meets the doing business requirement by virtue of meeting at least one of these safe harbors. It should also be noted and appreciated that the 3(a)(11) exemption is construed narrowly. Meaning that ALL investors must be residence within the state. If thousands of investors are state residents but there is one out of state investor, including that one out of state investor is sufficient enough to disqualify the issuer from the 3(a)(11) exemption. Such is the reason why the 3(a)(11) exemption is not higher up on the preference list. Its strict application makes it a fragile exemption that can easily break.

Regulation A - "Regulation A" - again referring to another regulation that the SEC promulgated under the ' 33 Act. Regulation A was revised fairly recently pursuant to the J.O.B.S. Act. ${ }^{164}$ The prior version was so onerous and cumbersome that practitioners rarely, if ever, used it as an exempt offering option. ${ }^{165}$ The prior Regulation A version limited the

16317 C.F.R. § 230.147(c)(2)(i)-(iv) (2021).

${ }^{164}$ On March 25, 2015, the Securities and Exchange Commission (the "Commission") adopted final rules to implement Section 401 of the Jumpstart Our Business Startups (JOBS) Act by expanding Regulation A into two tiers: Tier 1, for securities offerings of up to $\$ 20$ million in a 12month period; and Tier 2, for securities offerings of up to $\$ 50$ million in a 12 -month period. An issuer of $\$ 20$ million or less of securities can elect to proceed under either Tier 1 or Tier 2. The 2015 amendments to Regulation A built on the prior Regulation A and preserved, with some modifications, the prior provisions regarding issuer eligibility, offering circular contents, testing the waters, and "bad actor" disqualification. The 2015 amendments modernized the Regulation A filing process for all offerings, aligned practice in certain areas with prevailing practice for registered offerings, created additional flexibility for issuers in the offering process, and established an ongoing reporting regime for certain Regulation A issuers. Amendments to Regulation A: A Small Business Guide, SEC, https://www.sec.gov/info/smallbus/secg/regulation-a-amendmentssecg.shtml [https://perma.cc/G67L-QB5Q]; see also 17 C.F.R. § 230.251(b) (2014) (pre-J.O.B.S. Act) (amended in 2015 by 17 C.F.R. $\S$ 230).

${ }^{165}$ For a full discussion on the Regulation A phenomena and its near extinction before being revived through the J.O.B.S Act, see Neal Newman, Let Sleeping Regs Lie: A Diatribe on Regulation A's Futility Before and After the J.O.B.S. Act, 18 U. PA. J. Bus. L. 65, 68 (2015), 
offering size to $\$ 5$ million, but the disclosure and reporting requirements were significant. ${ }^{166}$ Practitioners deemed the cost of doing a Regulation A offering as far outweighing the benefits. ${ }^{167}$ Thus, the Regulation A exemption was rarely used. That is until the J.O.B.S. Act came along and made significant revisions to the Regulation A offering exemption.

The new Regulation A, often referred to as Regulation A+, features a two-tiered offering system with the first tier covering offerings up to $\$ 20$ million, and the second tier allowing for offerings up to $\$ 50$ million. ${ }^{168}$ Attractive aspects to the new Regulation A+ exemption are the following:

1. Investors need not be accredited or have any type of special sophistication which means that the issuer can offer these securities to anyone. ${ }^{169}$

2. The Securities aren't restricted - which means that the securities can be re-sold without the issuer having to register them or find an applicable exemption.

3. As mentioned earlier, the offering cap is $\$ 50$ million which is enough to meet capital raising needs of most smaller privately owned companies. ${ }^{170}$

On the less attractive side, the disclosure provisions are "robust." Regulation A+ requires significant financial and business disclosures upon the initial offering, plus the issuer is mandated to provide ongoing periodic financial and business disclosures. ${ }^{171}$ In spite of the author's expectations to

https://scholarship.law.upenn.edu/jbl/vol18/iss1/3

[https://perma.cc/4YYK-X3H6].

${ }^{166}$ See id. at 72 .

${ }^{167} \mathrm{Id}$.

16817 C.F.R. § 230.251(a)(1)-(2) (2021). NOTE: In November 2020, the SEC "...voted to amend its rules in order to harmonize, simplify, and improve the multilayer and overly complex exempt offering framework." Among other things, these rule changes will raise the cap on Regulation A's Tier 2 offerings from $\$ 50$ million to $\$ 75$ million. See Press Release, SEC, SEC Harmonizes and Improves "Patchwork" Exempt Offering Framework (Nov. 2, 2020), https://www.sec.gov/news/press-release/2020273 [https://perma.cc/TNR5-7ZVH].

${ }^{169}$ Regulation A consists of Rules 251-263. No investor qualifications such as net income, net worth, or investor sophistication are noted in any of these rules. See Regulation A: Rules 251-263. However, Regulation A does limit the amount a non-accredited investor can invest. That amount is generally $10 \%$ of their net income or $10 \%$ of their net worth - whichever is greater. See Regulation A Rule 251(d)(2)(C).

${ }^{170}$ For Tier 2 offerings for Regulation A, the offering amount can be up to $\$ 50$ million - see Regulation A Rule 251(a)(2).

${ }^{171}$ See 17 C.F.R. § 230.257(a) (2021) (for Tier 1 filers); see 17 C.F.R. § 230.257(b) (2021) (for Tier 2 filers). 
the contrary, Regulation A+ has proven to be quite popular among issuers. When Regulation A+ users were questioned as to why they chose to do their offering under Regulation A+ instead of the more often used Regulation D, issuers explained that not having to worry about whether the investors were accredited was a huge factor in their decision. ${ }^{172}$ Also, the author thought that the ongoing periodic reporting requirement would have been a big deterrent as well. When issuers were questioned about this aspect, their response was interesting. Most of these companies were very much expecting that they would soon be publicly traded companies anyway so they thought it good form and "best practices" to get used to those requirements. The author thought that was an interesting response given the high failure rate for most of these companies. "Pessimist" and

"entrepreneur" are rarely used in the same sentence.

The Crowdfunding Exemption

The final private offering exemption to be discussed is the Crowdfunding exemption. Perhaps the private exemption most familiar to the general public because of the fact that it harkens back to the "go fund me" efforts which is the premise upon which the Crowdfunding exemption was built. Under the crowdfunding exemption, issuers can offer up to $\$ 5,000,000$ in securities in any twelve month period without having to register the offering. ${ }^{173}$ Under the crowdfunding provision, the amount any one issuer can invest is capped. ${ }^{174}$ The cap is based on the investor's net income or net worth. For investors whose net worth or annual income is less than $\$ 107,000$ annually, the amount the investor can invest is capped at the greater of $\$ 2,200$ or five percent of either the investor's annual income or their net worth; whichever is less. ${ }^{175}$

If the investor's annual income or net worth is greater than $\$ 100,000$ then the amount the investor can invest is $10 \%$ of the investor's annual income or net worth, where the investment amount cannot exceed $\$ 107,000$ in any event. ${ }^{176}$ Again, the design here is to limit the exposure or the risk of loss by limiting the aggregate offering amount allowed and by limiting the amount that anyone investor can invest. Caps on the offering

${ }^{172}$ Neal Newman, Regulation A+: New and Improved after the JOBS Act or a Failed Revival, 12 VA. L. \& Bus. REV. 243, 271 (2018) (providing a full discussion regarding Regulation $\mathrm{A}$ issuers and their decision making process for choosing the Regulation A exemption).

${ }^{173}$ See 17 C.F.R. § 227.100(a)(1) (2021); In November 2020, the SEC “ ...voted to amend its rules in order to harmonize, simplify, and improve the multilayer and overly complex exempt offering framework." Among other things, these rule changes will raise the offering limit on Regulation Crowdfunding from $\$ 1.07$ million to $\$ 5$ million. See Press Release 2020273, SEC, SEC Harmonizes and Improves "Patchwork" Exempt Offering Framework (Nov. 2, 2020), https://www.sec.gov/news/press-release/2020273 [https://perma.cc/QM7C-LRF7].

17417 C.F.R. § 227.100(a)(1)-(2) (2021).

${ }^{175} \mathrm{Id}$ \$ 227.100(a)(2)(i).

${ }^{176} I d$. § 227.100(a)(2)(ii). 
size and how much any one investor can invest makes the crowdfunding exemption self-restraining.

The key for practitioners and issuers alike is to find the exemption(s) that fit best. Ideally, both short term and long-term considerations are factored into the decision. Historically, Regulation D's Rule 506(b) provision has been the most often used. But times are changing. There is a feeling that it's time to open up the investor pool and look beyond what has historically been a place occupied by the wealthy with their accredited investor status. Private exemptions like Regulation A+ are opening the door to a wider pool of investors and are allowing more people to build wealth through investing while at the same time participating in growing the economy.

\section{DIVISION OF ENFORCEMENT}

With the SEC Division of Enforcement's annual report for fiscal year 2020 we find, "a comprehensive view of the Division's accomplishments over the past year, [discussion about] significant actions and key areas of strategic change, and details of the Division's COVID-19related enforcement efforts." ${ }^{177}$ SEC Chairman at the time Jay Clayton states, "This year's report highlights Enforcement's extraordinary efforts across the country to identify wrongdoing and take meaningful action to protect American investors from misconduct, including in the face of the many challenges imposed by COVID-19." ${ }^{\prime 18}$ Working both at headquarters and in the eleven regional offices, the SEC during FY2020:

brought a diverse mix of 715 enforcement actions, including 405 standalone actions. These actions addressed a broad range of significant issues, including issuer disclosure and accounting violations; foreign bribery; investment advisory issues; securities offerings; market manipulation; insider trading; and broker-dealer misconduct. Through these actions, the SEC obtained judgments and orders totaling approximately $\$ 4.68$ billion in disgorgement and penaltiesa record amount for the Commission-and returned more than $\$ 600$ million to harmed investors. Significantly, through the Division's efforts, the SEC awarded a record \$175 million to 39 whistleblowers in fiscal year 2020, both the highest dollar amount and the highest number of individuals awarded in any year. ${ }^{179}$

${ }^{177}$ Press Release 2020-274, SEC, SEC Division of Enforcement Publishes Annual Report for Fiscal Year 2020, (Nov. 2, 2020), https://www.sec.gov/news/press-release/2020-274 [https://perma.cc/C2UX-88YS].

${ }^{178} I$ Id.

${ }^{179} \mathrm{Id}$. 
Division of Enforcement Director Stephanie Avakian observes that during FY2020, "the Division continued to investigate and recommend actions addressing conduct that spanned the securities markets, including conduct involving financial fraud, insider trading, offering fraud, Foreign Corrupt Practices Act violations, misconduct by broker-dealers and investment advisors, and more. . . the Commission brought hundreds of enforcement actions and secured meaningful remedies. .."180 Exhibit 2 shows that most of the 405 standalone cases brought by the Commissions during FY "2020 concerned securities offerings (32\%), investment advisory and investment company issues (21\%), and issuer reporting/accounting and auditing (15\%) matters. The SEC also continued to bring actions relating to broker-dealers $(10 \%)$, insider trading $(8 \%)$, and market manipulation $(5 \%)$. . . Public Finance (3\%) and FCPA (2\%)."

Exhibit 2

Types of Cases ${ }^{182}$

${ }^{180}$ SEC 2020 ANNUAL REPORT, supra note 6, at 2.

${ }^{181} \mathrm{Id}$. at 16.

${ }^{182} I d$. at 18 . 


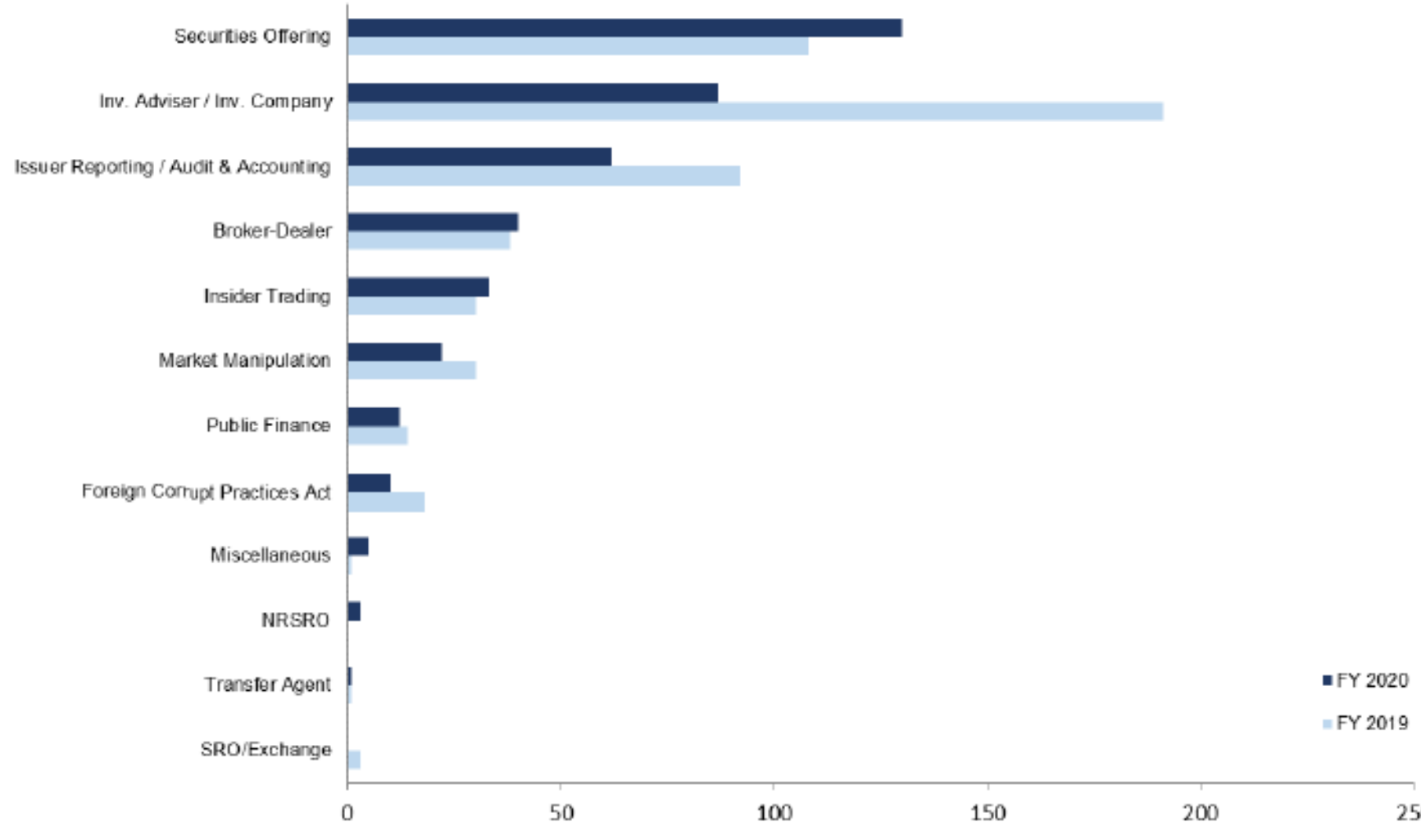

Presented in Exhibit 3 is a Summary Chart of Enforcement actions brought during fiscal year 2020 by the Commission by primary classification.

Exhibit 3

Summary of Enforcement actions for FY $2020^{183}$

183 Id at 29. 


\begin{tabular}{|c|c|c|c|c|c|c|}
\hline Primary Classification & $\begin{array}{c}\text { Civil } \\
\text { Actions }\end{array}$ & $\begin{array}{c}\text { Stand Alone } \\
\text { AP }\end{array}$ & $\begin{array}{c}\text { Follow-On } \\
\text { AP }\end{array}$ & Total & $\begin{array}{c}\text { \% of Total } \\
\text { Actions }\end{array}$ & $\begin{array}{l}\% \text { of Civil ant } \\
\text { Standalone Al } \\
\text { IEucluding } \\
\text { Dilng err Filng }\end{array}$ \\
\hline Broker-Dealer & $14(26)$ & $26(28)$ & $102(108)$ & $142(162)$ & $20 \%$ & $10 \%$ \\
\hline Delinquent Filings & $D(0)$ & $130(165)$ & $0(0)$ & $130(165)$ & $18 \%$ & $0 \%$ \\
\hline Foreign Corrupt Practices Act & $3(3)$ & $7(7)$ & $0(0)$ & $10(10)$ & $1 \%$ & $2 \%$ \\
\hline Insider Trading & $21(47)$ & $12(12)$ & $0(0)$ & $33(59)$ & $5 \%$ & $8 \%$ \\
\hline Investment Advisors/ Investment Companies & $30(64)$ & $57(76)$ & $50(51)$ & 137 (191) & $19 \%$ & $21 \%$ \\
\hline Issuer Reporting / Audit \& Accounting & $12(29)$ & $50(60)$ & $12(12)$ & 74 (101) & $10 \%$ & $15 \%$ \\
\hline Market Manipulation & $19(113)$ & $3(3)$ & $6(6)$ & $28(122)$ & $4 \%$ & $5 \%$ \\
\hline Miscellaneous & $1(3)$ & $4(5)$ & $1(1)$ & $6(9)$ & $1 \%$ & $1 \%$ \\
\hline NRSRO & $0(0)$ & $3(3)$ & $1(1)$ & $4(4)$ & $1 \%$ & $1 \%$ \\
\hline Public Finance Abuse & $2(4)$ & $10(13)$ & $0(0)$ & $12(17)$ & $2 \%$ & $3 \%$ \\
\hline Securities Offering & $103(330)$ & $27(40)$ & $8(8)$ & $138(378)$ & $19 \%$ & $32 \%$ \\
\hline Transfer Agent & $D(0)$ & $1(1)$ & $0(0)$ & $1(1)$ & $0 \%$ & $0 \%$ \\
\hline Totals & $205(619)$ & $330(413)$ & $180(187)$ & $715(1,219)$ & $100 \%$ & $100 \%$ \\
\hline
\end{tabular}

Comprehensive coverage of the Division of Enforcement is beyond the scope of this one law review article. However, a better understanding of the important work of the Commission is achieved by taking a closer look at various areas of enforcement activities. Accordingly, we will now present a summary of some of the major issues and challenges confronting the Commission, including such topics as: accounting fraud; COVID-19 abuses; misconduct by Issuers and Registrants; holding individuals accountable; protecting retail investors; improving the pace of investigations; rewarding cooperation; and the Foreign Corrupt Practices Act (FCPA).

\section{Accounting Fraud}

While many of the activities of the Division of Enforcement may fall into one of the other categories we will discuss during the next few pages, those arising from some sort of accounting fraud are all too common. Accordingly, we provide in Exhibit 4 just one example of the many that are representative.

\section{Exhibit 4}

Luckin Coffee Agrees to Pay

\$180 Million Penalty to Settle Accounting Fraud Charges 


\section{FOR IMMEDIATE RELEASE}

\section{0-319}

Washington D.C., Dec. 16, 2020 -

The Securities and Exchange Commission today charged China-based company Luckin Coffee Inc. with defrauding investors by materially misstating the company's revenue, expenses, and net operating loss in an effort to falsely appear to achieve rapid growth and increased profitability and to meet the company's earnings estimates. Luckin, whose American Depositary Shares traded on Nasdaq until July 13, 2020, has agreed to pay a \$180 million penalty to resolve the charges.

The SEC's complaint alleges that, from at least April 2019 through January 2020, Luckin intentionally fabricated more than $\$ 300$ million in retail sales by using related parties to create false sales transactions through three separate purchasing schemes. According to the complaint, certain Luckin employees attempted to conceal the fraud by inflating the company's expenses by more than $\$ 190$ million, creating a fake operations database, and altering accounting and bank records to reflect the false sales.

The complaint further alleges that the company intentionally and materially overstated its reported revenue and expenses and materially understated its net loss in its publicly disclosed financial statements in 2019. For example, Luckin allegedly materially overstated its reported revenue by approximately $28 \%$ for the period ending June 30,2019 , and by $45 \%$ for the period ending Sept. 30, 2019, in its publicly disclosed financial statements. The complaint alleges that during the period of the fraud, Luckin raised more than $\$ 864$ million from debt and equity investors. After Luckin's misconduct was discovered in the course of the annual external audit of the company's financial statements, Luckin reported the matter to and cooperated with SEC staff, initiated an internal investigation, terminated certain personnel, and added internal accounting controls.

"Public issuers who access our markets, regardless of where they are located, must not provide false or misleading information to investors," said Stephanie Avakian, Director of the SEC's Division of Enforcement. "While there are challenges in our ability to effectively hold foreign issuers and their officers and directors accountable to the same extent as U.S. issuers and persons, we will continue to use all our available resources to protect investors when foreign issuers violate the federal securities laws." 
"The SEC's complaint alleges that Luckin's disclosures to investors about its revenues were false," said Carolyn M. Welshhans, Associate Director of the SEC's Division of Enforcement. "The settlement with Luckin is designed to help ensure that harmed investors have the best available opportunity to receive relief."

The SEC's complaint, filed today in the Southern District of New York, charges Luckin with violating the antifraud, reporting, books and records, and internal control provisions of the federal securities laws. Without admitting or denying the allegations, Luckin has agreed to a settlement, subject to court approval, that includes permanent injunctions and the payment of a $\$ 180$ million penalty. This payment may be offset by certain payments Luckin makes to its security holders in connection with its provisional liquidation proceeding in the Cayman Islands. The transfer of funds to the security holders will be subject to approval by Chinese authorities. . ${ }^{184}$

\section{Covid-19 Pandemic}

Former Enforcement Division Director Stephanie Avakian writes, "the real story of 2020 was COVID-19. It colored so much of the last half of the year-what we focused on, investigations we opened, actions we recommended, how we did our work, where we did our work, and how we allocated our resources." ${ }^{185}$ Reflecting during November 2020, Director Avakian writes:

By mid-March, the entire Division had transitioned to mandatory telework and essentially all of our operations were conducted remotely. Despite this shift in working conditions-and the still ongoing efforts to adapt to those conditions-we quickly dedicated substantial resources to address the emerging threats presented by COVID-19 and the ensuing dynamic market conditions. At the same time, we continue to focus on the multitude of existing and new non-COVID-related enforcement issues arising in the normal course. . .

${ }^{184}$ Press Release 2020-319, SEC, Luckin Coffee Agrees to Pay $\$ 180$ Million Penalty to Settle Accounting Fraud Charges (Dec. 16, 2020), https://www.sec.gov/news/press-release/2020-319 [https://perma.cc/5STPA25L].

${ }^{185}$ Id. See also Eddie Bernice Johnson \& Lawrence J. Trautman, The Demographics of Death: An Early Look at Covid-19, Cultural and Racial Bias in America, 48 Hastings Const. L.Q. 357 (2021) (describing the impact of early months of the pandemic), http://ssrn.com/abstract=3677607 [https://perma.cc/BZ6J-C4A8]. 
First, we quickly committed substantial resources to protecting retail investors by actively looking for misconduct. In March, we formed a Coronavirus Steering Committee to oversee this effort by coordinating investigations relating to a wide variety of potential misconduct in the areas of microcap, insider trading, and financial fraud and issuer disclosure. . .

In March and April alone, the Commission suspended trading in the securities of two dozen issuers where there were questions regarding the accuracy and adequacy of information related to COVID-19 that those issuers injected into the marketplace, including claims about potential COVID-19 treatments, the manufacture and sale of personal protection equipment, and disaster response capabilities.

All told, from mid-March through the end of the fiscal year, the Division's Office of Market Intelligence triaged approximately 16,000 tips, complaints, and referrals (a roughly $71 \%$ increase over the same time period last year), and the Division opened more than 150 COVID-related inquiries and investigations and recommended several COVID-related fraud actions to the Commission. We think this triage and investigative work, and the resulting Commission trading suspensions and fraud actions, meaningfully changed the landscape for investors during a period of significant market uncertainty. . .

In the early months of the pandemic, many of us spent the bulk of our time focused on learning and guiding our staff how to effectively do our job remotely. But we moved past that initial period of uncertainty and ultimately achieved a remarkable level of success, including bringing more than 700 enforcement cases during the fiscal year. Viewed against the backdrop of COVID-19, this was an extraordinary accomplishment. ${ }^{186}$

The COVID-19 pandemic has presented numerous violations of securities law. Just one example of alleged fraud violations is represented by the following SEC press release, SEC Charges Biotech Company and CEO With Fraud Concerning COVID-19 Blood Testing Device, found in Exhibit 5.

Exhibit 5

SEC Charges Biotech Company and CEO With Fraud Concerning COVID-19 Blood Testing Device

${ }^{186}$ SEC 2020 ANNUAL REPORT, supra note 6, at 2. 
FOR IMMEDIATE RELEASE

2020-327

Washington D.C., Dec. 18, 2020 -

The Securities and Exchange Commission today announced charges against California-based biotechnology company Decision Diagnostics Corp. and its CEO, Keith Berman, with making false and misleading claims in numerous press releases that the company had developed a working, break-through technology that could accurately detect Covid-19 through a quick blood test. The SEC temporarily suspended trading in Decision Diagnostics' securities on April 23, 2020.

The SEC's complaint alleges that Decision Diagnostics and Berman seized upon the global pandemic through a series of press releases that falsely claimed Decision Diagnostics had developed a finger prick blood test that could detect Covid-19 in less than a minute. According to the complaint, from March 2020 to at least June 2020, Decision Diagnostics and Berman made false and misleading statements about the existence of Decision Diagnostics' Covid-19 device and progress towards FDA emergency use authorization. As alleged, at the time of these claims, Decision Diagnostics lacked a proven method for detecting the virus and had no physical testing device. Further, its advisors had warned that the testing kit they were trying to manufacture would not work as Decision Diagnostics had described. The complaint also alleges that the statements created the misleading impression that the test was soon to be introduced to the market and led to surges in the price and trading volume of Decision Diagnostics' stock.

"During this unprecedented time, when the need for truthful disclosures concerning Covid-19 tests is of vital importance, Decision Diagnostics and its CEO allegedly misled investors by claiming to have made a working test device when all they had was an idea that had not materialized into a product," said Stephanie Avakian, Director of the Division of Enforcement. "With the onset of the global pandemic, we quickly pivoted to identify potential areas of fraud. This case is another example of how the Commission will hold accountable those who exploit the pandemic to harm investors."

"In our complaint, we allege that Decision Diagnostics and Berman repeatedly made baseless representations to the investing public about market-moving events like progress in obtaining FDA approval and having breakthrough technology," said Anita B. Bandy, Associate 
Director of the Division of Enforcement. "Today's filing is a credit to the dedicated SEC staff, who continued to investigate after the trading suspension and quickly uncovered the alleged fraud."

The complaint, filed in the U.S. District Court for the Southern District of New York, charges Decision Diagnostics and Berman with violating antifraud provisions of the securities laws. The SEC is seeking a court order permanently enjoining both Decision Diagnostics and Berman from directly or indirectly violating those provisions and ordering them to pay civil penalties.

The Department of Justice's Market Integrity and Major Frauds Unit announced today that parallel criminal charges against Berman were also filed in the U.S. District Court for the District of Columbia. ${ }^{187}$

\section{Misconduct By Issuers and Registrants}

The SEC states that "A cornerstone of our enforcement program is ensuring that entities are held accountable for their misconduct." 188 During FY2020, the SEC "brought actions against financial institutions, automobile and engine manufacturers, and technology, telecommunications, and pharmaceutical companies, to name a few." 189 While a number of examples are listed in the 2020 Annual Report for the Division of Enforcement, the following are representative:

- Wells Fargo \& Co. In a settled action, the Commission found that Wells Fargo misled investors about the success of its core business strategy at a time when it was opening unauthorized or fraudulent accounts for unknowing customers and selling unnecessary products that went unused. Wells Fargo was ordered to pay the SEC a $\$ 500$ million penalty as part of a combined $\$ 3$ billion settlement with the SEC and the Department of Justice.

- Telegram Group Inc. The Commission filed an emergency action and obtained a temporary restraining order against Telegram and its wholly-owned subsidiary TON Issuer Inc. for allegedly operating an unregistered offering of digital tokens called 'Grams' in violation of the federal securities laws. On the Commission's motion, the court issued a preliminary injunction barring

${ }^{187}$ Press Release 2020-327, SEC, SEC Charges Biotech Company and CEO With Fraud Concerning COVID-19 Blood Testing Device (Dec. 18, 2020), https://www.sec.gov/news/press-release/2020-327

[https://perma.cc/5ECT-Z4J8]. ${ }^{188}$ SEC 2020 ANNUAL REPORT, supra note 6, at 3.

${ }^{189} \mathrm{Id}$. 
the delivery of Grams and finding that the Commission had shown a substantial likelihood of proving that Telegram's sales were part of a larger scheme to unlawfully distribute the Grams to the secondary public market. Following this decision, the defendants agreed to settle the action and were ordered to return more than $\$ 1.2$ billion to investors and pay an $\$ 18.5$ million civil penalty.

- Bausch Health, formerly Valeant Pharmaceuticals. In a settled action, the Commission found that Valeant improperly recognized revenue and made misleading disclosures in SEC filings and earnings presentations. Bausch was ordered to pay a $\$ 45$ million civil penalty. ${ }^{190}$

An instructive example representative of the many actions brought by the Commission falling under the category of "misconduct by issuers and registrants" is found in the 2021 press release SEC Charges Vuuzle Media Corp. and Affiliated Individuals in Connection With \$14 Million Offering Fraud, as shown in Exhibit 6.

\section{Exhibit 6}

SEC Charges Vuuzle Media Corp. and Affiliated Individuals in Connection With \$14 Million Offering Fraud

\section{FOR IMMEDIATE RELEASE}

\section{1-18}

Washington D.C., Jan. 27, $2021-$

The Securities and Exchange Commission today charged Vuuzle Media Corporation, a purported online live streaming and entertainment company, and its founder Ronald Shane Flynn (a.k.a. Ronnie Shane) with fraudulently offering over \$14 million in securities to investors across the United States using an aggressive boiler room sales scheme.

The SEC's complaint alleges that between 2016 and 2020, Vuuzle and Flynn raised more than $\$ 14$ million from individual investors using a boiler room of salespeople employing high-pressure tactics, based primarily in the Philippines. According to the complaint, Vuuzle and Flynn promised investors that Vuuzle was a legitimate and growing company and a "pre-IPO" investment opportunity when in fact Vuuzle has never made a profit and has never made a public offering on any stock exchange. As alleged, only a small fraction of investor funds went towards the online streaming business. The complaint further alleges that Flynn misappropriated $\$ 4.9$ million of investor funds for his

${ }^{190} I d$. 
personal use, including by using it to pay for jewelry, luxury flights and hotel stays, subscriptions to dating websites, and nightclub visits. Vuuzle and Flynn also allegedly used at least $\$ 5.5$ million of investor funds to sustain the boiler room and pay commissions to Flynn and others for recruiting investors. The complaint also charged Richard Marchitto with aiding and abetting Flynn and Vuuzle's fraud by allegedly acting as their U.S. corporate and financial presence and maintaining a U.S. bank account, corporate credit cards, and a New York office address for Vuuzle.

"We are committed to taking action to protect investors and pursuing relief for those who have been harmed," said Melissa Hodgman, Acting Director of the SEC's Division of Enforcement. "We will vigorously pursue fraudsters who enrich themselves at investors' expense."

"The defendants allegedly raised millions of dollars from investors through aggressive and deceptive sales techniques, and misappropriated the majority of those funds for personal use and to fund the boiler room operation," said Jennifer S. Leete, Associate Director in the SEC's Division of Enforcement. "Investors should be on alert for red flags of investor fraud such as unsolicited calls and high pressure sales tactics."

The complaint, filed in federal court in the District of New Jersey, charges Vuuzle and Flynn with violating the antifraud and registration provisions of the federal securities laws, and Marchitto with aiding and abetting Vuuzle and Flynn's violations. The SEC seeks permanent injunctive relief, disgorgement with prejudgment interest, and civil penalties against each defendant. . ${ }^{191}$

\section{Holding Individuals Accountable}

To better understand how the regulation of markets and those involved in the securities industry is conducted, the SEC states, "We have long recognized that individual accountability is critical to an effective enforcement program. Institutions act through their employees, and holding culpable individuals responsible for wrongdoing is essential to achieving our goals of general and specific deterrence and protecting investors by removing bad actors from our markets." 192 The SEC takes action based upon a theory placing premium "on establishing individual liability where appropriate. In

${ }^{191}$ Press Release 2021-18, SEC, SEC Charges Vuuzle Media Corp. and Affiliated Individuals in Connection With \$14 Million Offering Fraud (Jan. 27, 2021), https://www.sec.gov/news/press-release/2021-18 [https://perma.cc/QF8L-KJZN].

192 SEC 2020 ANNUAL REPORT, supra note 6 at 4. 
Fiscal Year 2020, the Commission charges individuals in $72 \%$ of the standalone enforcement actions it brought.." ${ }^{193}$ Consider:

Those charged include individuals at the top of the corporate hierarchy, including numerous CEOs and CFOs, as well as accountants, auditors, and other gatekeepers. Just by way of example, former executives of Valeant Pharmaceuticals, Goldman Sachs Group Inc., and Iconix Brand Group Inc., as well as former audit partners of KPMG LLP, were charged with a range of violations, including fraud, reporting, books and records, and internal accounting controls. ${ }^{194}$

\section{Protecting Retail Investors}

The Commission continues to bring actions "involving the conduct of investment professionals as it relates to retail investors." 195 For example, during Fiscal Year 2020 the Division of Enforcement "filed an action against Wells Fargo for failing reasonably to supervise investment advisers and registered representatives who recommended complex, high-volatility single-inverse ETFs to retail investors, and for lacking adequate compliance policies and procedures with respect to the suitability of those recommendations." 196 A penalty of $\$ 35$ million was imposed to resolve this matter, with proceeds distributed to harmed investors. ${ }^{197}$ In sum, for the fiscal year, the Commission reports having "distributed more than $\$ 600$ million to harmed investors. ${ }^{" 198}$ Exhibit 7 depicts just one example of an action brought to protect retail investors.

\section{Exhibit 7}

SEC Charges Boiler Rooms Operator with Defrauding Retail Investors

\section{FOR IMMEDIATE RELEASE}

2020-298

Washington D.C., Dec. 1, 2020 -

The SEC today charged New York resident Mark Alan Lisser with fraud for operating at least two boiler rooms, on Long Island, New York and in Boca Raton, Florida, through which he raised approximately \$2.1 million from at least 71 retail investors and misappropriated more than $\$ 900,000$ of their funds.

According to the SEC's complaint, from approximately October 2018 to March 2019, Lisser, and salespeople that he directed in the boiler rooms, solicited
${ }^{193} \mathrm{Id}$.
${ }^{194} \mathrm{Id}$.
${ }^{195} I d$.
${ }^{196} \mathrm{Id}$. at 5 .
${ }^{197} I d$.
${ }^{198} I d$. 
investors for Knightsbridge Capital Partners, an unregistered fund manager he operated, by misrepresenting that the Knightsbridge-managed funds had purchased "pre-IPO" shares in three well-known companies directly from employees of the companies. As the complaint alleges, Knightsbridge did not own any shares at the time it solicited investors and subsequently purchased shares or interests in shares of the companies from third parties, not employees. Additionally, as alleged in the complaint, Knightsbridge never owned enough shares to cover the sales it had made to investors.

The complaint further alleges that Lisser and his salespeople falsely claimed to investors that Knightsbridge only charged investors a fee based on the profits after the pre-IPO companies went public, such that Knightsbridge and the investors were on the "same side of the trade," despite significantly marking up sales and charging commissions. According to the complaint, Lisser misappropriated over $\$ 900,000$ of investor funds, including by transferring some of the funds to his personal bank account and using investor funds to pay credit card bills.

"As alleged in the complaint, Lisser victimized dozens of retail investors through high pressure sales tactics, misrepresentations and misappropriation of their funds," said Richard R. Best, Director of the SEC's New York Regional Office. "This case demonstrates our continuing commitment to hold accountable those who operate oldfashioned boiler rooms to solicit investors' hard-earned savings."

The SEC's complaint, filed in federal court for the Eastern District of New York, charges Lisser with violations of the antifraud provisions of the Securities Act of 1933 and the Securities Exchange Act of 1934, and seeks injunctive relief, disgorgement plus prejudgment interest, and civil penalties.

In a parallel action, the U.S. Attorney's Office for the Eastern District of New York earlier today filed criminal charges against Lisser. ${ }^{199}$

\section{Investigation Pace Accelerated}

During FY 2020, Enforcement continued its goal, "to focus on shortening the amount of time it takes to complete investigations and

199 Press Release 2020-298, SEC, SEC Charges Boiler Rooms Operator with Defrauding Retail Investors (Dec. 1, 2020), https://www.sec.gov/news/press-release/2020-298 [https://perma.cc/S2SJBBBM]. 
recommend enforcement actions. Our actions have the greatest impact when filed as close in time to the conduct as possible. Our median time to file this past year was 21.6 months-a five year best." ${ }^{\text {200 }}$ The Enforcement Division states:

More specifically, we have also seen improvements in the length of time it takes to bring financial fraud and issuer disclosure cases. In appropriate cases, we are increasing staffing, working to more efficiently triage issues, making more targeted requests at the onset, substantively engaging early in an investigation with relevant parties, and leveraging cooperation. These changes have had the desired effect: in Fiscal Year 2020, we reduced the average amount of time it takes to complete these investigations from 37 months to 34 months. Some notable examples include settled charges against a Bermuda-based insurance company for failing to fully disclose perquisites and benefits provided to its former chief executive officer, brought fifteen months after the Division opened an investigation, and a settled action against Hilton Worldwide Holdings Inc. addressing similar violations, brought roughly eight months after the Division began its investigation. . . ${ }^{201}$

\section{$\underline{\text { Rewarding Cooperation }}$}

The SEC often provides incentives to issuers or individuals under investigation for their meaningful cooperation. To increase efficiency, the Commission during FY 2020, "continued to focus on rewarding cooperation and providing greater transparency into how the Commission considers and weighs cooperation credit." 202 Accordingly, Enforcement provides two examples-"in one the Commission ordered a reduced penalty in recognition of substantial cooperation and in the other the Commission determined to not impose a penalty at all." ${ }^{203}$ Accordingly:

In the Commission's action against BMU, the Commission imposed a reduced civil penalty against BMW in recognition of its extensive cooperation, especially in light of COVID19 challenges. Despite considerable constraints, including travel restrictions, work-from-home orders, and office closures, BMW gathered and made available a large volume of information in response to document, information, and data requests. BMW also made multiple current and former employees available for interviews, and provided presentations and narrative submissions that highlighted

\footnotetext{
${ }^{200} I d$. at 6.

${ }^{201} I d$.

${ }^{202} I d$.

${ }^{203} \mathrm{Id}$.
} 
critical facts. Due in large part to this cooperation, we were able to complete this case within 12 months of opening it.

In the Commission's action against Transamerica Asset Management, Inc., a registered investment adviser based in Denver, Colorado, the Commission did not impose a penalty where Transamerica self-reported the conduct, took prompt steps to remediate the violations, and cooperated with the staff's investigation. We recognize the value in communicating such examples of meaningful cooperation and will continue to look for opportunities to improve our messaging going forward. ${ }^{204}$

An example of the Commission rewarding instances of cooperation is found in the last paragraph of the press release regarding settled charges brought against The Cheesecake Factory for COVID-19-related disclosure violations. This information is presented in Exhibit 8.

Exhibit 8

SEC Charges The Cheesecake Factory For Misleading COVID-19

Disclosures

\section{FOR IMMEDIATE RELEASE}

\section{0-306}

Washington D.C., Dec. 4, 2020

The Securities and Exchange Commission today announced settled charges against The Cheesecake Factory Incorporated for making misleading disclosures about the impact of the COVID-19 pandemic on its business operations and financial condition. The action is the SEC's first charging a public company for misleading investors about the financial effects of the pandemic.

As set forth in the SEC's order, in its SEC filings on March 23 and April 3, 2020, The Cheesecake Factory stated that its restaurants were "operating sustainably" during the COVID-19 pandemic. According to the order, the filings were materially false and misleading because the company's internal documents at the time showed that the company was losing approximately $\$ 6$ million in cash per week and that it projected that it had only 16 weeks of cash remaining. The order finds that although the company did not disclose this internal information in its March 23 and April 3 filings, the company did share this information with potential private equity investors or lenders in connection with an effort to seek additional liquidity. The order also finds that, although the March 23 filing described actions the company had undertaken to preserve financial flexibility during the

${ }^{204} I d$. 
pandemic, it failed to disclose that The Cheesecake Factory had already informed its landlords that it would not pay rent in April due to the impacts that COVID-19 inflicted on its business.

"During the pandemic, many public companies have discharged their disclosure obligations in a commendable manner, working proactively to keep investors informed of the current and anticipated material impacts of COVID-19 on their operations and financial condition," said SEC Chairman Jay Clayton. "As our local and national response to the pandemic evolves, it is important that issuers continue their proactive, principles-based approach to disclosure, tailoring these disclosures to the firm and industry-specific effects of the pandemic on their business and operations. It is also important that issuers who make materially false or misleading statements regarding the pandemic's impact on their business and operations be held accountable."

"When public companies describe for investors the impact of COVID-19 on their business, they must speak accurately," said Stephanie Avakian, Director of the Division of Enforcement. "The Enforcement Division, including the Coronavirus Steering Committee, will continue to scrutinize COVID-related disclosures to ensure that investors receive accurate, timely information, while also giving appropriate credit for prompt and substantial cooperation in investigations."

The SEC's order finds that The Cheesecake Factory violated reporting provisions of the federal securities laws. Without admitting the findings in the order, The Cheesecake Factory agreed to pay a $\$ 125,000$ penalty and to cease-anddesist from further violations of the charged provisions. In determining to accept the settlement, the SEC considered the cooperation afforded by The Cheesecake Factory... ${ }^{205}$

\section{Foreign Corrupt Practice Act (FCPA)}

Trautman and Altenbaumer-Price observe, "The societal cancer of bribery, extortion, or corruption in any of its various forms exacts an unacceptable toll on all citizens of the world." ${ }^{\text {206 }}$ Pervasive global bribery

${ }^{205}$ Press Release 2020-306, SEC, SEC Charges The Cheesecake Factory For Misleading COVID-19 Disclosures (Dec. 4, 2020), https://www.sec.gov/news/press-release/2020-306 [https://perma.cc/7GWH-U4X4].

${ }^{206}$ Lawrence J. Trautman \& Kara Altenbaumer-Price, Foreign Corrupt Practices Act: An Update on Enforcement and SEC and DOJ Guidance, 41 SEC. REG. L.J. 241 (2013), http://ssrn.com/abstract=2293382 [https://perma.cc/JAF7-26LC]. 
and corruption results in starving populations, the movement of millions of refugees into often unwelcoming neighboring countries, leading to political instability. This familiar scenario, resulting from bribery and corruption is a root cause of war. Recent history in the Middle East confirms research by Transparency International, "that Egypt, Lebanon, Morocco and Palestine all suffer from unchecked executive power and lack access to information laws and whistleblower protection legislation, greatly hindering citizens' ability to report and stop corruption practices."207

In sum, The Foreign Corrupt Practices Act (FCPA) primarily addresses two distinct activities: bribery and improper record-keeping. In relevant part, the statute prohibits (1) payments of anything of value to foreign officials "in order to assist [the payor] in obtaining or retaining business for or with, or directing business to, any person;"208 and (2) failing to keep records and books "which, in reasonable detail, accurately and fairly reflect the transactions and dispositions of the assets of the issuer."209 Therefore, "When the FCPA is read as a whole, its core of criminality is seen to be bribery of a foreign official to induce him to perform an official duty in a corrupt manner." 210

These prohibitions within the statute apply to virtually every company, whether public or private, or person that touches the United States. Four categories of actors are covered: (1) "issuers" (public companies) ${ }^{211}$ (2) any business with its principal place of business in the United States or that is organized under the laws of any state, territory, possession, or

${ }^{207}$ Id. at 241 (citing Transparency International, Annual Report 2010, 84). See also Norman D. Bishara, Governance and Corruption Constraints in the Middle East: Overcoming the Business Ethics Glass Ceiling, 48 AM. Bus. L.J. 227 (2011); Philip M. Nichols, The Business Case for Complying With Bribery Laws, 49 AM. Bus. L.J. 325 (2012); Lawrence J. Trautman, Following the Money: Lessons from the "Panama Papers,"

Part 1: Tip of the Iceberg, 121 PenN ST. L. Rev. 807 (2017), http://ssrn.com/abstract=2783503 [https://perma.cc/QQL3-4BG7]. 20815 U.S.C. $\S 78 \mathrm{dd}-1(\mathrm{a})(1)(\mathrm{B})$.

20915 U.S.C. $\S 78 \mathrm{~m} \mathrm{(b)(2)(A).}$

${ }^{210}$ United States v. Kay, 359 F.3d 738, 761 (5th Cir. 2004); see also Gideon Mark, Private FCPA Enforcement, 49 AM. Bus. L.J. 419 (2012);

Steven R. Salbu, Mitigating the Harshness of FCPA Enforcement Through a Qualifying Good-Faith Compliance Defense, 55 AM. Bus. L.J. 475 (2018); Steven R. Salbu, Redeeming Extraterritorial Bribery and Corruption Laws, 54 AM. Bus. L.J. 641 (2017); Lawrence J. Trautman \& Kara Altenbaumer-Price, Lawyers, Guns and Money - The Bribery Problem and U.K. Bribery Act, 47 INT'L LAW. 481 (2013), http://www.ssrn.com/abstract=2276738 [https://perma.cc/P2AZ-N9XV].

${ }^{211}$ Issuers include both U.S. public companies, as well as foreign companies whose shares trade on U.S. exchanges. See, e.g., At Siemens, Bribery Was Just a Line Item, N.Y. TIMES, Dec. 20, 2008 (where the Justice Department prosecuted Siemens AG, a major German multinational with shares trading on the New York Stock Exchange, therefore, a foreign issuer; but, subject to provisions of the FCPA). 
commonwealth of the United States (private companies); ${ }^{212}$ (3) United States citizens, nationals, and residents; and (4) other persons who take any act in furtherance of the corrupt payment while within the territory of the United States. $^{213}$

The Fifth Circuit, in United States v. Kay, considered one of the most comprehensive FPCA cases, ${ }^{214}$ explained the anti-bribery portion of the statute as criminalizing:

only those payments that are intended to (1) influence a foreign official to act or make a decision in his official capacity, or (2) induce such official to perform or refrain from performing some act in violation of his duty, or (3) secure some wrongful advantage to the payor. And even then, the FCPA criminalizes these kinds of payments only if the result they are intended to produce - their quid pro quo - will assist (or is intended to assist) the payor in efforts to get or keep some business for or with "any person.".215

In order to be criminally liable under the FCPA, the person making, promising, or offering the payment must have a "corrupt intent" and " $[t]$ he payment must be intended to induce to the recipient to misuse his [or her] official position to direct business wrongfully to the payer." 116 Indeed, "the word 'corruptly' in the FCPA signifies, in addition to the element of 'general intent' present in most criminal statutes, a bad or wrongful purpose and an intent to influence a foreign official to misuse his official position." ${ }^{217}$ While the bribe must be to a foreign official, "[i]t should be noted that the business to be obtained does not need to be with a foreign government or foreign government instrumentality;" rather it need only be with any person or entity

21215 U.S.C. $\S 78 \mathrm{dd}-2(\mathrm{~h})(\mathrm{B})$ (referred to as "domestic concerns" under the statute).

${ }^{213} 15$ USC $\S 78$ dd-1; 15 U.S.C. $\S 78$ dd-2(h).

${ }^{214}$ United States v. Kozeny, 493 F. Supp. 2d 693, 705 (S.D.N.Y. 2007)

(referencing the Fifth Circuit's "'ad nauseum' review of the legislative history of the FCPA" in United States v. Kay, 359 F.3d 738, 761 (5th Cir. 2004)).

${ }^{215}$ Kay, 359 F.3d at $740-41$.

${ }^{216}$ See The United States Dep't of Justice, U.S. Attorney Criminal RESOURCE MANUAL, 1018 (2000), https://web.archive.org/web/20040124193754/http:/www.justice.gov/usao /eousa/foia_reading_room/usam/title $9 / \mathrm{crm} 01018 . \mathrm{htm}$ [https://perma.cc/P83F-QJR4?type=image].

${ }^{217}$ Kozeny, 493 F. Supp. $2 \mathrm{~d}$ at 704 . Although, violators lacking the requisite scienter may still be held to have violated the SEC's record-keeping rules. 
within the foreign country. ${ }^{218}$ All that matters is that the giver of the bribe intends the receiver to do something. ${ }^{219}$ The meaning of "foreign official" is quite broad, including employees of partially state-owned or state-run entities - such as national hospitals, airlines, or oil companies - or private entities handling a government function. ${ }^{220}$ Indeed, in a country like China where many businesses are partially or wholly state-owned, virtually anyone can be a government official. ${ }^{221}$

In addition to anti-bribery provisions, the FCPA also contains record-keeping provisions that apply to public companies and are enforced by the SEC. ${ }^{22}$ The FCPA makes it a crime to "make false or misleading entries on a company's books for any purpose whatsoever." ${ }^{223}$ Indeed, even proper "facilitating payments" violate the FCPA if they are not properly accounted for. ${ }^{224}$ These accounting provisions do not apply to foreign subsidiaries who are not "issuers" of securities in the American market. ${ }^{225}$ However, where an "issuer" has majority interest in a foreign subsidiary, it must ensure the subsidiary has adequate internal accounting controls in place. ${ }^{226}$ When a wholly owned subsidiary violates the books and records provisions, parent corporations are civilly liable regardless of whether the parent company had any knowledge. ${ }^{227}$

${ }^{218}$ The United States DeP'T OF Justice, U.S. DOJ Layperson's Guide TO THE FCPA, http://www.justice.gov/criminal/fraud/fcpa/docs/laypersons-guide.pdf.

219 Aaron G. Murphy, Practitioner Note: The Migratory Patterns of Business in the Global Village, 2 N.Y.U.J.L. \& Bus. 218, at 237 n.31 (2005).

${ }^{220}$ See 15 U.S.C. $\S 78 \mathrm{dd}-2(\mathrm{~h})(2)$.

${ }^{221}$ Lawrence J. Trautman, American Entrepreneur in China: Potholes on the Silk Road to Prosperity, 12 WAKE ForeST J. BuS. \& INTELL. Prop. L. 427 (2012), http://www.ssrn.com/abstract=1995076

[https://perma.cc/9GTE-KNJ5].

22215 U.S.C. $\$ 78 \mathrm{~m}-1$.

${ }^{223}$ O. Thomas Johnson, Jr., Foreign Corrupt Practices Act, 1 Best ABA Sec.: Gen. Prac., Solo \& SMall Firm Sec. 38 (1997).

${ }^{224}$ The United States Dep'T OF Justice, U.S. AtTorney CRiminal RESOURCE MANUAL supra note 216. Interestingly, Deloitte Financial Advisory Services recommends firms set up a separate facilitation payments account and make all such payments out of it. Deloitte Financial Advisory Services LLP Advisory, Foreign Corrupt Practices Act leading practice considerations (2006).

${ }^{225}$ United States v. Kay, 359 F.3d 738, 754 (5th Cir. 2004).

${ }^{226} \mathrm{Id}$. at 755 .

227 The United States Department of Justice, U.S. DOJ LAyperson's GUIDE TO THE FCPA supra note 218; see also Lawrence J. Trautman \& Kara Altenbaumer-Price, The Foreign Corrupt Practices Act: Minefield for Directors, 6 VA. L. \& BUS. REV. 145, 146-47 (2011), http://www.ssrn.com/abstract=1930190 [https://perma.cc/U22E-9X9S]; Lawrence J. Trautman \& Joanna Kimbell, Bribery and Corruption: The 
We are including language in Exhibit 9 from the 2008 press release announcing the landmark settlement with Siemens AG regarding worldwide bribery. When internal legal and compliance expenses are included, this litigation is regarded as having cost the company well over $\$ 1.5$ billion (US).

\section{Exhibit 9}

SEC Charges Siemens AG for Engaging in Worldwide Bribery

\section{FOR IMMEDIATE RELEASE}

2008-294

Washington D.C., Dec. 15, 2008 -

The Securities and Exchange Commission today announced an unprecedented settlement with Siemens AG to resolve SEC charges that the Munich, Germany-based manufacturer of industrial and consumer products violated the Foreign Corrupt Practices Act (FCPA) by engaging in a systematic practice of paying bribes to foreign government officials to obtain business...

The SEC alleges that Siemens paid bribes on such widespread transactions as the design and construction of metro transit lines in Venezuela, power plants in Israel, and refineries in Mexico. Siemens also used bribes to obtain such business as developing mobile telephone networks in Bangladesh, national identity cards in Argentina, and medical devices in Vietnam, China, and Russia. According to the SEC's complaint, Siemens also paid kickbacks to Iraqi ministries in connection with sales of power stations and equipment to Iraq under the United Nations Oil for Food Program. Siemens earned more than $\$ 1.1$ billion in profits on these and several other transactions.

Siemens has agreed to pay $\$ 350$ million in disgorgement to settle the SEC's charges, and a $\$ 450$ million fine to the U.S. Department of Justice to settle criminal charges. Siemens also will pay a fine of approximately $\$ 569$ million to the Office of the Prosecutor General in Munich, to whom the company previously paid an approximately \$285 million fine in October 2007...

The SEC's complaint alleges that between March 12, 2001, and Sept. 30, 2007, Siemens created elaborate payment schemes to conceal the nature of its corrupt payments, and the company's inadequate internal controls allowed the conduct to flourish. Siemens made thousands of payments to third parties in ways that obscured the purpose

COSO Framework, FCPA, and U.K. Bribery Act, 30 FLA. J. INT'L L. 191 (2018), http://ssrn.com/abstract=3239193 [https://perma.cc/6DKUQVC3]. 
for, and the ultimate receipt of, the money. Employees obtained large amounts of cash from cash desks, which were sometimes transported in suitcases across international borders for bribery. The authorizations for payments were placed on post-it notes and later removed to eradicate any permanent record. Siemens used numerous slush funds, offbooks accounts maintained at unconsolidated entities, and a system of business consultants and intermediaries to facilitate the corrupt payments. Siemens made at least 4,283 payments, totaling approximately $\$ 1.4$ billion, to bribe government officials in return for business to Siemens around the world. In addition, Siemens made approximately \$391 million, which were not properly controlled and were used, at least in part, for such illicit purposes as commercial bribery and embezzlement.

The misconduct involved employees at all levels, including former senior management, and reveled a corporate culture long at odds with the FCPA. The SEC's complaint alleges that despite the company's knowledge of bribery at two of its largest groups-Communications and Power Generation- the tone at the top at Siemens was inconsistent with an effective FCPA compliance program and created a corporate culture in which bribery was tolerated and even rewarded at the highest levels of the company. In November, 2006, Siemen's current management began to implement reforms to the company's internal controls, which substantially reduced, but did not entirely eliminate, corrupt payments. All but $\$ 27.5$ million of the corrupt payments occurred before Nov. 15, 2006.

Siemens violated Section 30A of the Securities Exchange Act of 1934 (Exchange Act) by making illicit payments to foreign government officials in order to obtain or retain business. Siemens violated Section 13(b)(2)(B) of the Exchange Act by failing to have adequate internal controls to detect and prevent the payments. Siemens violated Section 13(b)(2)(A) of the Exchange Act by improperly recording the payments on its books and records... ${ }^{228}$

Some cases like the Siemens case illustrated above continue with related matters being brought for years, as shown by the 2018 announcement of a guilty plea reached in a matter dating back to 1998 involving an

${ }^{228}$ Press Release 2008-294, SEC, SEC Charges Siemens AG for Engaging in Worldwide Bribery

(Dec. 15, 2008), https://www.sec.gov/news/press/2008/2008-294.htm [https://perma.cc/6EPG-U6U4]. 
admission of engaging, "in a decade-long scheme to pay tens of millions of dollars in bribes to Argentine government officials in connection with a [national identity card] project, which was worth more than $\$ 1$ billion to Siemens. $" 229$ An example of a more contemporary FCPA case is provided in Exhibit 10, involving charges against Deutsche Bank.

\section{Exhibit 10}

SEC Charges Deutsche Bank

With FCPA Violations Related to Third-Party Intermediaries

\section{FOR IMMEDIATE RELEASE}

2021-3

Washington D.C., Jan. 8, 2021 -

The Securities and Exchange Commission today announced charges against Deutsche Bank AG for violations of the Foreign Corrupt Practices Act (FCPA). As part of coordinated resolutions with the SEC and the Department of Justice, Deutsche Bank has agreed to pay more than $\$ 120$ million, which includes more than $\$ 43$ million to settle the SEC's charges.

According to the SEC's order, Deutsche Bank engaged foreign officials, their relatives, and their associates as third-party intermediaries, business development consultants, and finders to obtain and retain global business. The order finds that Deutsche Bank lacked sufficient internal accounting controls related to the use and payment of such intermediaries, resulting in approximately $\$ 7$ million in bribe payments or payments for unknown, undocumented, or unauthorized services. The order further finds that these payments were inaccurately recorded as legitimate business expenses and involved invoices and documentation falsified by Deutsche Bank employees.

"While third parties can assist in legitimate business development activities, it is critical that companies have sufficient internal accounting controls in place to prevent payments to third parties in furtherance of improper purposes," said Charles Cain, Chief of the SEC Enforcement Division's FCPA Unit.

The SEC's order finds that Deutsche Bank violated the books and records and internal accounting controls provisions of the Securities Exchange Act of 1934. Deutsche Bank agreed to a cease-and-desist order and to pay disgorgement of $\$ 35$ million with prejudgment interest of $\$ 8$

${ }^{229}$ Press Release, Dep't of Justice, Former Siemens Executive Pleads Guilty to Role in $\$ 100$ Million Foreign Bribery Scheme (March 15, 2018), https://www.justice.gov/opa/pr/former-siemens-executive-pleads-guiltyrole-100-million-foreign-bribery-scheme [https://perma.cc/DZ38-495R]. 
million to settle the action. The SEC did not impose a civil penalty in light of the $\$ 79$ million criminal penalty paid in the criminal resolution... ${ }^{230}$

\section{CORPORATE GOVERNANCE AND THE SEC}

It was Chief Justice John Marshall who provided us with the definition of a corporation when he wrote, "Corporations are artificial beings, invisible, intangible, and existing only in contemplation of law."231 Accordingly, it is these state-granted charters that create corporations, "their governance dictated by state law, with corporate directors responsible for managing the affairs of the corporation..." ${ }^{232}$ Under Delaware law, directors owe their corporation and shareholders fiduciary duties of care and loyalty. ${ }^{233}$

${ }^{230}$ Press Release 2021-3, SEC, SEC Charges Deutsche Bank With FCPA Violations Related to Third-Party Intermediaries (Jan. 8, 2021), https://www.sec.gov/news/press-release/2021-3_[https://perma.cc/N45M5HWA].

${ }^{231}$ Trs. of Dartmouth College v. Woodward, 17 U.S. 518, 636 (1819) (opinion of Marshall, C.J.); see also Todd Haugh, Nudging Corporate Compliance, 54 Am. Bus. L.J. 683 (2017).

${ }^{232}$ Lawrence J. Trautman, The Matrix: The Board's Responsibility for Director Selection and Recruitment, 11 FLA. ST. U. Bus. REV. 75, 78 (2012), http://www.ssrn.com/abstract=1998489_[https://perma.cc/C46UE6LY] (citing Del. Code ANN. tit. 8, § 141(a) (West 1991) ("The business and affairs of a corporation organized under this chapter shall be managed by or under the direction of a board of directors, except as may be otherwise provided in this chapter or in its certificate of incorporation.")). While more than half of all publicly-owned United States corporations are chartered under the laws of the state of Delaware, corporate counsel and directors will want to closely examine the laws of relevant states when considering any particular matter; see also Gilson \& Kraakman, Delaware's Intermediate Standard for Defensive Tactics: Is There Substance to Proportionality Review?, 44 Bus. Law. 247, 248 (Feb. 1989) ("Delaware corporate law... governs the largest proportion of the largest business transactions in history"); see Bradley R. Aronstam, The Interplay of Blasius and Unocal-A Compelling Problem Justifying the Call for Substantial Change, 81 OR. L. REV. 429, 429-30 n.4 (2002) (why corporations prefer Delaware as their choice for incorporation); see also Lawrence J. Trautman, Who Sits on Texas Corporate Boards? Texas Corporate Directors: Who They Are and What They Do, 16 Hous. Bus. \& TAX L.J. 44 (2016), http://ssrn.com/abstract=2493569 [https://perma.cc/J4GD-WGTD]. ${ }^{233}$ Smith v. Van Gorkom, 488 A.2d 858 (Del. 1985); see also Guth v. Loft, A.2d 503, 510 (Del. 1939) (the duty of loyalty in Delaware requiring that there shall be no conflict between duty and self-interest). 
The Duties and Responsibilities of Corporate Directors

Volumes have been written about corporate governance and the role directors play in representing shareholders and other stakeholders in the oversight of corporate entities. We will not attempt to duplicate that effort here, given the space limitations imposed on law review articles. However, more on this topic is provided in the footnote below. ${ }^{234}$ In sum, the primary duties of care and loyalty are the legal standards determining acceptable conduct for all boards and their directors. ${ }^{235}$

${ }^{234}$ John Armour, Henry Hansmann \& Reinier H. Kraakman, The Essential Elements of Corporate Law (Oxford Leg. Stud. Res., Working Paper No. 134, 2009), https://ssrn.com/abstract=1436551_[https://perma.cc/AL7FDR5A]; Stephen Mark Bainbridge, Director Primacy and Shareholder Disempowerment, 119 HARV. L. REV. 119, 119-20 (2006), https://ssrn.com/abstract=808584 [https://perma.cc/4PF7-2JHY]; Lucian A. Bebchuk, Alma Cohen \& Allen Ferrell, What Matters in Corporate Governance?, 22 REV. FIN. STUD. 783, 787 (2009), https://ssrn.com/abstract=593423 [https://perma.cc/L7BM-MBZU]; Lucian A. Bebchuk \& Jesse M. Fried, Pay Without Performance: Overview of the Issues, 30 J. CORP. L. 647 (2005), https://ssrn.com/abstract=761970 [https://perma.cc/9RZH-DGW9]; Lawrence D. Brown \& Marcus L. Caylor, Corporate Governance and Firm Valuation, 25 J. ACCT. \& PUB. POL'y 409, 410-11 (2006), https://ssrn.com/abstract=754484 [https://perma.cc/9WMJ-NRUJ]; Brian R. Cheffins, The History of Corporate Governance, in OXFORD HANDBOOK OF CORPORATE GOVERnANCe (Mike Wright, Donald Siegel, Kevin Keasey \& Igor Filatotchev eds., Oxford U. Press, 2013), https://ssrn.com/abstract=1975404 [https://perma.cc/W24K-JKVP]; John C. Coffee, A Theory of Corporate Scandals: Why the U.S. And Europe Differ (The Ctr. for L. and Econ. Stud., Working Paper No. 274, 2005), https://ssrn.com/abstract=694581 [https://perma.cc/T79Y-SNHY]; Jeffrey N. Gordon, Systematic Stewardship (Colum. L. and Econ., Working Paper No. 640, 2021), https://ssrn.com/abstract $=3782814$

[https://perma.cc/XBG8-JJVA]; Michael C. Jensen, Agency Costs of Overvalued Equity, 34 Fin. Mgmt. (2005), https://ssrn.com/abstract=704025 [https://perma.cc/9XSX-DGMT]; Donald C. Langevoort \& Hillary A. Sale, Corporate Adolescence: Why Did 'We' not Work?, Geo. U. L. CTR. (Jan. 8, 2021), https://ssrn.com/abstract=3762718 [https://perma.cc/X7DS-D3VK]; Veronica Root Martinez \& Gina-Gail S. Fletcher, Equality Metrics, 130 YALE L.J. F. 869 (2021), https://ssrn.com/abstract=3772895 [https://perma.cc/8LXG-PTXS].

${ }^{235}$ Lawrence J. Trautman, The Board's Responsibility for Crisis Governance, 13 Hastings Bus. L.J. 275, 282 (2017), http://ssrn.com/abstract=2623219 [https://perma.cc/823T-3E7D]; Lawrence J. Trautman, Present at the Creation: Reflections on the Early Years of the National Association of Corporate Directors, 17 DuQ. Bus. L.J. 1, 1-2 (2015), http://ssrn.com/abstract=2296427 [https://perma.cc/APR7-XMLD]. 


\section{How Boards Organize Their Work}

For efficiency purposes, boards divide the individual work of directors into standing committees. A particularly up-to-date discussion of the role of the primary standing committees found on almost all public company boards (audit, compensation, and nominating and governance committees) is provided by seasoned corporate directors: Seletha Butler; Michele Hooper; Ron McCray; and Ruth Simmons. ${ }^{236}$ Often, areas of financial and other organizational risk will be assigned to the Audit Committee, requiring that members of this committee be recruited for unique talents and experiences. ${ }^{237}$

\section{D\&O Insurance}

Elsewhere Trautman and Altenbaumer-Price reflect, "It is unquestioned in today's business and litigation climate that corporate officers and directors face significant exposure based simply on their roles and titles, no matter how effectively, carefully, or in good faith their decisions are made." ${ }^{238}$ Because of this risk, "Director and officer insurance, called D\&O, is designed to protect executives, outside directors, as well as the companies they serve against liability arising from actions taken in the course of doing business." ${ }^{239}$ Consider that claims brought: Against officers and directors come in many forms, ranging from common law claims for breach of fiduciary duty to shareholder class actions for violations of the securities laws. Even when these allegations are baseless, companiesas well as individual directors and officers-may still face significant defense and settlement costs. D\&O insurance, in tandem with indemnification, is designed to protect against the legal expenses of fighting litigation, as well as the underlying liability exposure. ${ }^{240}$

${ }^{236}$ Lawrence J. Trautman, Seletha Butler, Frederick Chang, Michele Hooper, Ron McCray \& Ruth Simmons, Corporate Directors: Who They Are, What They Do, Cyber and Other Contemporary Challenges, 70 BufF. L. REV. (forthcoming 2021) (Professor Fred Chang providing an excellent discussion about cybersecurity issues and challenges). ${ }^{237}$ Lawrence J. Trautman, Who Qualifies as an Audit Committee Financial Expert Under SEC Regulations and NYSE Rules?, 11 DEPAUL Bus. \& CoM. L.J. 205, 213 (2013), http://www.ssrn.com/abstract=2137747_[https://perma.cc/A43W-49TH]. ${ }^{238}$ Lawrence J. Trautman \& Kara Altenbaumer-Price, $D \& O$ Insurance: $A$ Primer, 1 AM. U. Bus. L. REV. 337, 337 (2012), http://www.ssrn.com/abstract=1998080[https://perma.cc/K67E-8AWR]. ${ }^{239} \mathrm{Id}$.

${ }^{240} I d$. 


\section{GOVERNING TECHNOLOGY CHALLENGES}

As Deputy Attorney General Mark R. Filip observes over a decade ago, "the infrastructure of the Internet is largely blind to national boundaries and the speed with which communications occur today allows for websites owned by people in Europe in Europe to be controlled from a location in Asia and to be actually housed in California." 241 In addition to proposing a specific cybersecurity standard of care, ${ }^{242}$ Professors Trautman and Ormerod write:

The two chief sources of authority from which corporate governance data security obligations flow are SarbanesOxley $^{243}$ and the SEC's 2011 guidance. ${ }^{244}$ Sarbanes-Oxley requires public companies to implement appropriate information security controls with regard to companies' financial information. ${ }^{245}$ The SEC's 2011 guidance identifies risks to cybersecurity as potential material information that companies are required to disclose under pre-existing securities law disclosure requirements and accounting standards. ${ }^{246}$

As 2021 begins, corporate boards and U.S. government agencies are still trying to understand the full impact of the SolarWinds hack, "one of

${ }^{241}$ Mark R. Filip, Remarks Prepared for Delivery by Deputy Attorney General Mark R. Filip at the International Conference on Cyber Security (Jan. 7, 2009), in DeP'T Just. NeWs, Jan. 2009,

https://www.justice.gov/opa/speech/remarks-prepared-delivery-deputyattorney-general-mark-r-filip-international-conference

[https://perma.cc/M28Z-7MYG]; see also Lawrence J. Trautman, Rapid Technological Change and U.S. Entrepreneurial Risk in International Markets: Focus on Data Security, Information Privacy, Bribery and Corruption, 49 CAP. U. L. REV. 67 (2021), https://ssrn.com/abstract=2912072 [https://perma.cc/N7N6-GMDS]. ${ }^{242}$ Lawrence J. Trautman \& Peter C. Ormerod, Corporate Directors' and Officers' Cybersecurity Standard of Care: The Yahoo Data Breach, 66 AM. U. L. REV. 1231, 1236 (2017), http://ssrn.com/abstract=2883607 [https://perma.cc/AD5Q-9NFQ].

${ }^{243}$ Id. at 1237 (citing The Sarbanes-Oxley Act of 2002, Pub. L. No. 107204, 116 Stat. 745 (codified as amended throughout U.S.C. titles 15, 18, 28, \& 29)).

${ }^{244}$ SEC, Corporate Finance Disclosure Guidance: Topic No. 2 (Oct. 13, 2011), https://www.sec.gov/divisions/corpfin/guidance/cfguidancetopic2.htm [https://perma.cc/U9LQ-5VXM].

${ }^{245}$ Bruce H. Nearon, Jon Stanley, Steven W. Teppler, \& Joseph Burton, Life after Sarbanes-Oxley: The Merger of Information Security and Accountability, 45 JURIMETRICS J. 379 (2005).

${ }^{246}$ Trautman \& Ormerod, supra note 242, at 1236-37. 
the worst in U.S. history." ${ }^{247}$ The Wall Street Journal reports, "Dozens of SolarWinds' customers, including major technology companies such as Microsoft Corp. and Cisco Systems Inc., were affected by the incident, as well as the departments of the Treasury, Justice, Energy, Commerce, State, Homeland Security, Labor and Energy." ${ }^{248}$ Professors Larcker, Reiss and Tayan write, "the board of directors is expected to ensure that management has identified and developed processes to mitigate risks facing the organization, including risks arising from data theft and the loss of proprietary information. Unfortunately, general observation suggests that companies are not doing a sufficient job of securing this data."249

\section{Challenge of Technology}

Existing for just a little more than a decade, "Bitcoin and other virtual currencies have had a major societal impact, and proven to be a unique payment systems challenge for law enforcement, financial regulatory authorities worldwide, and the investment community."250 Elsewhere, Professor Trautman observes, "Rapid introduction and diffusion of technological changes throughout society, such as the blockchain that serves as Bitcoin's crypto-foundation, continue to exceed the ability of law

${ }^{247}$ Robert McMillan, Hackers Lurked in SolarWinds Email System for at Least 9 Months, CEO Says, WALL ST. J., (Feb. 2, 2021),

https://www.wsj.com/articles/hackers-lurked-in-solarwinds-email-systemfor-at-least-9-months-ceo-says-11612317963 [https://perma.cc/C7TKGDUS].

${ }^{248} I d$.

${ }^{249}$ David F. Larcker, Peter C. Reiss \& Brian Tayan, Critical Update

Needed: Cybersecurity Expertise in the Boardroom, in ROCK CTR. FOR Corp. Governance at Stan. U. Closer Look Series (No. CGRP-69,

Stan. U. Graduate Sch. of Bus. Research Paper No.17-702017), https://ssrn.com/abstract=3074594 [https://perma.cc/R6UZ-MNKM]; see also J. Robert Brown, The Demythification of the Board of Directors, 52 Am. Bus L.J. 131 (2015).

${ }^{250}$ Lawrence J. Trautman, Bitcoin, Virtual Currencies and the Struggle of Law and Regulation to Keep Pace, 102 MARQ. L. ReV. 447, 447 (2018), https://ssrn.com/abstract=3182867 [https://perma.cc/M43E-7T9L]; see also Lawrence J. Trautman \& Mason J. Molesky, A Primer for Blockchain, 88 UMKC L. REV. 239 (2019), https://ssrn.com/abstract=3324660 [https://perma.cc/CQ3R-5ZYU]; Lawrence J. Trautman, Mohammed T. Hussein, Louis Ngamassi \& Mason Molesky, Governance of The Internet of Things (IoT), 60(3) JURIMETRICS 315 (2020), http://ssrn.com/abstract=3443973 [https://perma.cc/U4GFF8SS]; Lawrence J. Trautman, Mohammed T. Hussein, Emmanuel U. Opara, Mason J. Molesky \& Shahedur Rahman, Posted: No Phishing, 8 EMORY CORP. GOV. \& ACCT. REV. 39, (2021), http://ssrn.com/abstract=3549992 [https://perma.cc/PT77-94JV]; Lawrence J. Trautman, Virtual Art and Non-fungible Tokens, 50 HOFSTRA LAW REVIEW (forthcoming), http://ssrn.com/abstract=3814087 [https://perma.cc/G2KN-PNT4]. 
and regulation to keep pace." ${ }^{251}$ Rapid growth of technology and the Internet has created challenges for the SEC, ${ }^{252}$ other regulators, ${ }^{253}$ Congress, ${ }^{254}$ corporate directors, ${ }^{255}$ and all of society. ${ }^{256}$

${ }^{251}$ Lawrence J. Trautman, Virtual Currencies: Bitcoin \& What Now After Liberty Reserve, Silk Road, and Mt. Gox?, 20 Rich. J. L. \& TeCH. 1, 13 (2014), http://www.ssrn.com/abstract=2393537 [https://perma.cc/7VFU$5 \mathrm{XDG}]$.

${ }^{252}$ Lawrence J. Trautman \& George P. Michaely, The SEC \& The Internet: Regulating the Web of Deceit, 68 CONSUMER FIN. L. Q. REP. 262 (2014), http://www.ssrn.com/abstract=1951148 [https://perma.cc/LMS3MD3T].

${ }^{253}$ David D. Schein \& Lawrence J. Trautman, The Dark Web and Employer Liability, 18 COLO. TECH. L.J., 1, 7 (2019), http://ssrn.com/abstract=3251479 [https://perma.cc/5H89-RQGV]; Lawrence J. Trautman \& Alvin Harrell, Bitcoin Versus Regulated Payment Systems: What Gives?, 38 CARDOzo L. ReV. 1041 (2017), http://ssrn.com/abstract=2730983 [https://perma.cc/P75U-362B]; Lawrence J. Trautman, Is Disruptive Blockchain Technology the Future of Financial Services?, 69 CONSUMER FIN. L. Q. REP. 232 (2016), http://ssrn.com/abstract=2786186 [https://perma.cc/HWP9-QHYR]. ${ }^{254}$ Lawrence J. Trautman, Congressional Cybersecurity Oversight: Who's Who \& How It Works, 5 J. L. \& CYBER WARFARE, 1, 17 (2016), http://ssrn.com/abstract=2638448 [https://perma.cc/Y63H-TXA5]; Lawrence J. Trautman, Cybersecurity: What About U.S. Policy?, 2015 U. ILL. J. L. TECH. \& POL'Y 341 (2015), http://ssrn.com/abstract=2548561 [https://perma.cc/YDZ9-CDVK].

${ }^{255}$ Lawrence J. Trautman, Governance of the Facebook Privacy Crisis, 20 PITT. J. TECH. L. \& POL'Y, 1, 41(2020), http://ssrn.com/abstract=3363002 [https://perma.cc/QA5R-7T3N]; Lawrence J. Trautman \& Peter C. Ormerod, WannaCry, Ransomware, and the Emerging Threat to Corporations, 86 TENN. L. REV. 503 (2019), http://ssrn.com/abstract=3238293 [https://perma.cc/SH25-QZKY]; Lawrence J. Trautman, How Google Perceives Customer Privacy, Cyber, E-Commerce, Political and Regulatory Compliance Risks, 10 WM. \& MARY BUS. L. REV. 1 (2018) https://ssrn.com/abstract=3067298 [https://perma.cc/C4US-P2GP]; Lawrence J. Trautman \& Peter C. Ormerod, Industrial Cyber Vulnerabilities: Lessons from Stuxnet and the Internet of Things, 72 U. MIAMI L. REV. 761 (2018), http://ssrn.com/abstract=2982629 [https://perma.cc/76MB-AK5N]; Lawrence J. Trautman, Managing Cyberthreat, 33 SANTA ClARA HIGH TECH. L.J. 230 (2016), http://ssrn.com/abstract $=2534119$ [https://perma.cc/5Q7V-CUNZ]; Lawrence J. Trautman, E-Commerce and Electronic Payment System Risks: Lessons from PayPal, 16 U.C. DAVIS Bus. L.J. 261 (2016), http://www.ssrn.com/abstract=2314119 [https://perma.cc/RB5X-R47F]; Lawrence J. Trautman \& Kara Altenbaumer-Price, The Board's Responsibility for Information Technology Governance, 28 J. MARSHALL J. COMP. \& INFO. L. 313 (2011), http://www.ssrn.com/abstract=1947283 [https://perma.cc/DXU3-6RB6]; Lawrence J. Trautman, Jason Triche \& James C. Wetherbe, Corporate 


\section{Cybersecurity and Financial Markets}

Like all aspects of society, cybersecurity threats impact global securities markets in numerous and ever-evolving ways too numerous to cover fully here. Breaches of business systems impact corporations raising liability issues from loss of customer privacy and information. Just one of these various exploits is discussed by the SEC's Office of Compliance Inspections and Examinations ("OCIE") observing "an increase in the number of cyber-attacks against SEC-registered investment advisers and brokers and dealers using credential stuffing, a method of cyber-attack to client accounts that uses compromised client login credentials, resulting in the possible loss of customer assets and unauthorized disclosure of sensitive personal information." 257

Innovation and Financial Technology

On December 3, 2020, the SEC announced a new stand-alone Office known as the Strategic Hub for Innovation and Financial Technology, referred to as "FinHub," and led by Valerie A. Szczepanik. In making this announcement, the Commission states:

Established within the Division of Corporation Finance in 2018, FinHub has spearheaded agency efforts to encourage responsible innovation in the financial sector, including in evolving areas such as distributed ledger technology and digital assets, automated investment advice, digital marketplace financing, and artificial intelligence and

Information Technology Governance Under Fire, 8 J. STRAT. \& INT'L STUD. 105 (2013), https://papers.ssrn.com/sol3/papers.cfm?abstract_id=2346583 [https://perma.cc/ZFF3-LAJ4].

${ }^{256}$ Robert W. Emerson \& Lawrence J. Trautman, Lessons About Franchise Risk From YUM! Brands and Schlotsky's, 24.3 LEWIS \& CLARK L. REV. 997 (2020), http://ssrn.com/abstract=3442905

[https://perma.cc/YPX4-HDEN]; Lawrence J. Trautman, Is Cyberattack The Next Pearl Harbor?, 18 N.C. J. L. \& TECH. 233 (2016), http://ssrn.com/abstract=2711059 [https://perma.cc/SEP7-23SA]; Lawrence J. Trautman \& Janet Ford, Nonprofit Governance: The Basics, 52 AKRON L. REV. 971 (2018), https://ssrn.com/abstract=3133818 [https://perma.cc/G4F4-B94P]; Lawrence J. Trautman, How Law Operates in a Wired Global Society: Cyber and E-Commerce Risk, PROCEEDS OF THE KOREA LEGISLATION RESEARCH INSTITUTE (KLRI), 2017 Legal Scholar Roundtable, Seoul, Korea, 21-22 Sept., 2017, https://ssrn.com/abstract=3033776 [https://perma.cc/9Q75-BHQM]. ${ }^{257}$ Announcement, SEC, Cybersecurity: Safeguarding Client Accounts Against Credential Compromise (Sept. 18, 2020), https://www.sec.gov/ocie/announcement/risk-alert-credential-compromise [https://perma.cc/63VH-TZ7R]; see also Amanda N. Craig, Scott J. Shackelford \& Janine S. Hiller, Proactive Cybersecurity: A Comparative Industry and Regulatory Analysis, 52 AM. BuS. L.J. 721 (2015). 
machine learning. Through FinHub, market and technology innovators as well as domestic and international regulators have been able to engage with SEC staff on new approaches to capital formation, trading, and other financial services within the parameters of the federal securities laws.

Designating FinHub as a stand-alone office strengthens the SEC's ability to continue fostering innovation in emerging technologies in our markets consistent with investor protection. The office will continue to lead the agency's work to identify and analyze emerging financial technologies affecting the future of the securities industry, and engage with market participants, as technologies develop. ${ }^{258}$

Virtual Currencies, Tokens, and the ICO Regulation Challenge

Recently, it has been observed that, "The SEC brings more enforcement actions against cryptoasset issuers, broker-dealers, cryptoexchanges, and other digital market participants than most other major crypto-jurisdictions, as well as the United States Commodity Futures Trading Commission. SEC enforcement results in considerably more serious penalties." 259

\section{CONTEMPORARY ISSUES}

The home page of the SEC website sets the stage for our discussion of contemporary challenges by illustrating the broad range of functions served by the Commission: "we inform and protect investors; we facilitate capital formation; we enforce federal securities laws; we regulate securities markets; and we provide data. ${ }^{260}$ As might be expected, challenges facing the SEC are limited only by the imagination of market participants. As a result, there are always numerous examples of interesting situations and fact patterns presenting challenges. Due to space limitations, we will now briefly discuss just a few: the Robinhood-Gamestop market volatility that takes place during January 2021; and the recent focus by the Commission on environmental, social, and governance (ESG) issues and developments.

\section{The Robinhood-GameStop Drama}

Year 2021 starts off with a major disruption to the volatility and stability of trading markets. In yet another example of Internet-related technology having impact on capital markets unimaginable just a few years

${ }^{258}$ Press Release 2020-303, SEC, SEC Announces Office Focused on Innovation and Financial Technology (Dec. 3, 2020), https://www.sec.gov/news/press-release/2020-303 [https://perma.cc/XGJ3-RY37].

${ }^{259}$ Yuliya Guseva \& Douglas Eakeley, Crypto-Enforcement Around the World, 94 S. CAL. L. REV. (forthcoming 2021), https://ssrn.com/abstract=3713198 [https://perma.cc/UT3R-WUSB]. ${ }^{260}$ SEC, https://www.sec.gov/ [https://perma.cc/3LA7-R8NS]. 
ago, The Wall Street Journal reports that Robinhood Markets Inc's chief executive Vlad Teney and "co-founder Baiju Bhatt, had set out eight years earlier to bring the stock market to a new class of investors. With engineers plucked from Facebook Inc. and other tech giants, they stripped down the trading experience and eliminated commissions, making buying stock about as easy... [as possible]." ${ }^{261}$ Success followed. Even in a "pandemic, throngs of amateur investors-homebound, bored and flush with stimulus checksopened Robinhood accounts to experience the market's thrills. By the end of December [2020], the firm had amassed about 20 million users... and weeks later the app hit the top of the download charts. ${ }^{262}$ In a memo to Members and staff of the U.S. House Committee on Financial Services the January 2021 market volatility and situation resulting in substantial monetary losses to many investors is described as follows:

\section{Overview}

In January 2021, retail investors on social media site Reddit's "WallStreetBets" subchannel ("subreddit") collectively executed an investment strategy to induce a short squeeze in stocks such as GameStop, AMC and KOSS, as well as other securities they identified as being heavily shorted by hedge funds. Meaning, social media users collectively drove the stock prices up, forcing short sellers who bet the stock price would go down, to purchase shares at an increased price. Reddit user, Keith Gill, notoriously discussed GameStop stock on Reddit under the username "DeepF*ckingValue." Initially, this squeeze led to heavy losses for some short sellers, particularly hedge funds, and led to substantial financial gain for some retail investors. Robinhood, and other broker dealers, placed restrictions on transactions in these stocks, which received public and regulatory scrutiny. Eventually, the stock prices started to decline and many investors were faced with steep financial losses. For some, the January short squeeze raises questions regarding whether legislators and regulators should take a closer look at existing rules governing short sales and related disclosures, as well as the conflicts between the practice of payment for order flow and firms' best execution obligations. It also raises important questions about the efficacy of anti-market manipulation laws and whether technology and social media have outpaced regulation in a manner that leaves investors and the markets exposed to unnecessary risks.

\section{Short Selling}

${ }^{261}$ Peter Rudegeair, Kirsten Grind \& Maureen Farrell, Robinhood's Reckoning: Facing Life After GameStop, WALL ST. J., Feb. 6-7, 2021, at A1.

${ }^{262} I d$. 
When an investor shorts a stock, they borrow the stock, typically from a broker, and then sells it to another investor. When the time comes for the borrower to return the borrowed stock, the borrower will purchase the stock in the market and return the stock to the lender. In a successful short sale, the market price of the borrowed stock will fall below the amount it costs to borrow the stock. When this happens, the borrower is then able to purchase the stock in the market at an amount lower than it cost the borrower to borrow the stock, return the stock to the lender, and keep the difference as profit. Some investors, such as hedge funds, engage this trading strategy when they are betting that the price of the securities will decline and expect they can profit from that decline. Others use this strategy to hedge against other market risks. The U.S. Securities and Exchange Commission (SEC) has repeatedly noted that short selling provides liquidity and price efficiency. The SEC has, however, implemented various rules to curb abusive short sale practices. ${ }^{263}$

Reports emerge, "The Reddit-fueled frenzy in stocks such as GameStop Corp. and AMC Entertainment Holdings Inc. is prompting calls for regulators to reconsider a decades-old practice in the U.S. stock market: payment for order flow." 264 Under this arrangement:

In which high-speed trading firms pay brokerages for the right to execute orders submitted by individual investors, has long been controversial. Some have said it warps the incentives of brokers and encourages them to maximize their revenue at the expense of customers. Supporters, including many brokers and trading firms, said it helps ensure investors get seamless executions and good prices on trades.

Last year, brokerages such as Charles Schwab Corp., TD Ameritrade, Robinhood Markets Inc. and $E^{*}$ Trade collected nearly $\$ 2.6$ billion in payments for stock and option orders, according to JMP Securities. The biggest sources of the payments were electronic-trading firms such as Citidel Securities, Susquehanna International Group LLP and Virtue Financial Inc.

${ }^{263}$ Memorandum from the U.S. House Comm. on Fin. Services from the Comm. Hearing Entitled "Game Stopped? Who Wins and Loses When Short Sellers, Social Media, and Retail Investors Collide?" (Feb. 18, 2021) (hereinafter "Memorandum"), https://financialservices.house.gov/calendar/eventsingle.aspx?EventID=40 7107 [https://perma.cc/TYU7-3HCE].

${ }^{264}$ Alexander Osipovich, GameStop Rally Fuels Scrutiny Of Payments to Online Brokers, Wall ST. J., Feb. 5, 2021, at A1. 
Payment for order flow helped set the stage for the manic trading in GameStop, whose shares began the year around $\$ 18$, surged to a record close of $\$ 347.51$ on Jan. 27 $[2021] \ldots{ }^{265}$

In testimony given on February 18, 2021, before the House Financial Services Committee, Gabriel Plotkin, founder and Chief Investment Officer of investment Melvin Capital Management states, "we had been short GameStop since Melvin's inception six years earlier because we believed and still believe that its business model-selling new and used video games in physical stores-is being overtaken by digital downloads through the internet." ${ }^{266}$ Mr. Plotkin further explains, "And that trend only accelerated in 2020, when, because of the pandemic, people were downloading video games at home. As a result, the gaming industry had its best year ever. But GameStop had significant losses." ${ }^{267}$ Mr. Melvin explains the fact pattern resulting in his being asked by the House Committee to explain the resulting market turmoil as follows:

\section{January Frenzy Untethered to Fundamentals}

In January 2021, a group on Reddit began to make posts about Melvin's specific investments. They took information contained in Melvin's SEC filings and encouraged others to trade in the opposite direction. Many of these posts were laced with antisemitic slurs directed at me and others. The posts said things like "it's very clear we need a second holocaust, the jews can't keep getting away with this." Others sent similarly profane and racist text messages to me.

In the frenzy during January, GameStop's stock rose from $\$ 17$ to a peak of $\$ 483$. I do not think anyone would claim that that price had any relationship to the intrinsic value of the company. The unfortunate part of this episode is that ordinary investors who were convinced by a misleading frenzy to buy GameStop at $\$ 100, \$ 200$, or even $\$ 483$ have now lost significant amounts.

When this frenzy began, Melvin started closing out its position in GameStop at a loss, not because our investment thesis had changed but because something unprecedented was happening. We also reduced many other

${ }^{265} I d$. Authors observe that GameStop shares closed at $\$ 179.84$ on December 1, 2021. YAHOO FINANCE, https://finance.yahoo.com/quote/GME?p=GME\&.tsrc=fin-srch [https://perma.cc/SBZ8-ALL4] (last visited Dec. 1, 2021). ${ }^{266}$ Game Stopped? Who Wins and Loses When Short Sellers, Social Media, and Retail Investors Collide; Hearing Before the H. Comm. on Fin. Services, 117th Cong. (2021) (statement of Mr. Gabriel Plotkin, Chief Exec. Offr. Melvin Capital Management LLP). ${ }^{267} I d$. 
Melvin positions at significant losses - both long and short - that were the subject of similar posts. ${ }^{268}$

Relevant securities laws involved with the December 2020-January 2021 GameStop et al., market volatility saga are described by the House Committee on Financial Services memorandum as follows:

U.S. securities laws prohibit fraud and market manipulation. Violations of these laws typically involve two categories of misconduct: (1) the spread false information in order to affect the price of a security, including pump-and-dump schemes; and (2) schemes in which bad actors individually or collectively transact to create false levels of volume or manipulate the price of a stock.

(i) Section 17(b) of the Securities Act of 1933

Section 17(b) of the Securities Act of 1933 makes it unlawful for a person to "tout", or publicize, a stock without discussing the nature of any payments or other consideration the person has been, or will be, paid. ${ }^{269}$

(ii) Section 9(a)(2) of the Exchange Act

Section $9(a)(2)$ prohibits transactions that directly or indirectly create actual or apparent active trading to induce the purchase or sale of a security by others. ${ }^{270}$ While Section 9 of the Exchange Act prohibits manipulation of securities prices, it requires the demonstration of specific intent "for the purpose of inducing the purchase or sale of such security by others" or "for the purposes of creating a false or misleading appearance of [market activity]."271

(iii) Rule 10(b)(5) \& FINRA Rule 2020

Rule 10b-5 makes it unlawful to "employ any device, scheme, or artifice to defraud", make material statements that are false or to omit material facts, or to "engage in any act, practice, or course of business which operates or would operate as a fraud or deceit upon any person, in connection with the purchase or sale of any security." ${ }^{272}$ To successfully establish a 10b-5 manipulation claim, the plaintiff must show that "(1) the defendant made a material misstatement or omission or used a fraudulent device; (2) she did so with scienter (that is, intent); (3) her conduct was related to the purchase or a sale of a security; (4) the plaintiff relied on the

\footnotetext{
${ }^{268} I d$.

${ }^{269} 15$ U.S.C. $\S 77 \mathrm{q}(\mathrm{b})$.

2707 U.S.C. $\$ 9(2)$.

271 15 U.S.C. $\$ 78 \mathrm{i}$.

27217 C.F.R. $\$ 240.10-b 5$.
} 
misstatement; and (5) the plaintiff was harmed." ${ }^{273}$ Rule $10(b)(5)$ is very broadly applied in various types of manipulation practices, including "marking the close," spoofing, scalping, etc. This is because "under Rule 10b-5, the fraudulent conduct alone can be indicative of the manipulator's deceptive intent." 274 Similarly, FINRA rule 2020 prevents FINRA members from making sales or purchases through manipulative, fraud or deceit. ${ }^{275}$

\section{Environmental, Social, and Governance (ESG) Issues}

The CFA Institute reports that, "ESG stands for Environmental, Social, and Governance. Investors are increasingly applying these nonfinancial factors as part of their analysis process to identify material risks and growth opportunities." ${ }^{, 276}$ In addition, "ESG metrics are not commonly part of mandatory part of financial reporting, though companies are increasingly making disclosures in their annual report or in a standalone sustainability report." 277

Efforts are now underway to define materiality, standards, and to incorporate these concepts into the investment process by such organizations as: the Global Reporting Initiative (GRI); the Sustainability Accounting Standards Board (SASB); and Task Force on Climate-related Financial Disclosures (TCFD), just to name a few. ${ }^{278}$ Among recent trends, "As ESG investing accelerates in demand, several trends are emerging-from climate change to social unrest. The coronavirus pandemic, in particular, has intensified discussions about the interconnectedness of sustainability and the financial system." 279 The SEC's March 4, 2021 press release, reproduced below as Exhibit 11, depicts the recent focus by the Commission on climate and ESG issues.

Exhibit 11

SEC Announces Enforcement Task Force Focused on Climate and ESG Issues

\section{FOR IMMEDIATE RELEASE}

2021-42

Washington D.C., March 4, 2021 -

${ }^{273}$ Memorandum, supra note 263 (citing Gina-Fail S. Fletcher, Legitimate Yet Manipulative: The Conundrum of Open-Market Manipulation (2018)).

${ }^{274}$ Id. (citing Arnold \& Porter, Criminal and Regulatory Enforcement of

Market Manipulation Spikes (July 21, 2016)).

${ }^{275}$ Memorandum, supra note 263, at 3.

${ }^{276}$ What is ESG Investing?, CFA InSTITUTE, https://www.cfainstitute.org/en/research/esg-investing [https://perma.cc/3T25-4P4E] (last viewed Mar. 5, 2021).

${ }^{277} I d$.

${ }^{278} I d$.

${ }^{279} \mathrm{Id}$. 
The Securities and Exchange Commission today announced the creation of a Climate and ESG Task Force in the Division of Enforcement. The task force will be led by Kelly L. Gibson, the Acting Deputy Director of Enforcement, who will oversee a Division-wide effort, with 22 members drawn from the SEC's headquarters, regional offices, and Enforcement specialized units.

Consistent with increasing investor focus and reliance on climate and ESG-related disclosure and investment, the Climate and ESG Task Force will develop initiatives to proactively identify ESG-related misconduct. The task force will also coordinate the effective use of Division resources, including through the use of sophisticated data analysis to mine and assess information across registrants, to identify potential violations.

The initial focus will be to identify any material gaps or misstatements in issuers' disclosure of climate risks under existing rules. The task force will also analyze disclosure and compliance issues relating to investment advisers' and funds' ESG strategies. Its work will complement the agency's other initiatives in this area, including the recent appointment of Satyam Khanna as a Senior Policy Advisor for Climate and ESG. As an integral component of the agency's efforts to address these risks to investors, the task force will work closely with other SEC Divisions and Offices, including the Divisions of Corporation Finance, Investment Management, and Examinations.

"Climate risks and sustainability are critical issues for the investing public and our capital markets," said Acting Chair Allison Herren Lee. "The task force announced today will play an important role in enhancing and coordinating the efforts of the Division of Enforcement, the Office of the Whistleblower, and other parts of the agency to bolster the efforts of the Commission as a whole on these vital matters."

"Proactively addressing emerging disclosure gaps that threaten investors and the market has always been core to the SEC's mission," said Acting Deputy Director of Enforcement Kelly L. Gibson, who will lead the task force. "This task force brings together a broad array of experience and expertise, which will allow us to better police the market, pursue misconduct, and protect investors."

In addition, the Climate and ESG Task Force will evaluate and pursue tips, referrals, and whistleblower complaints on ESG-related issues, and provide expertise and insight to teams working on ESG-related matters across the 
Division. ESG related tips, referrals and whistleblower complaints can be submitted here. ${ }^{280}$

\section{VIII.CONCLUSION}

During recent years, rapid technological change has resulted in novel regulatory issues and challenges, as law and policy struggles to keep pace. It is the role and responsibility of the U.S. Securities and Exchange Commission to monitor, regulate, and ensure that the U.S. capital markets continue as the deepest, most dynamic, and most liquid in the world. To a considerable extent, the success or failure of our society, jobs of a global workplace, and the ability of families everywhere to feed, clothe, and house themselves depends on the success of the SEC in providing fair and open access to capital through efficient markets.

${ }^{280}$ Press Release 2021-42, SEC, SEC Announces Enforcement Task Force Focused on Climate and ESG Issues (Mar. 4, 2021), https://www.sec.gov/news/press-release/2021-42 [https://perma.cc/4HAR$5 \mathrm{CTU}]$; see also Lawrence J. Trautman \& Neal Newman, The Environmental, Social and Governance (ESG) Debate Emerges from the Soil of Climate Denial (Oct. 10, 2021), http://ssrn.com/abstract=3939898 [https://perma.cc/HL2C-HL29]. 